$$
\begin{aligned}
& 269 \\
& 10-12-63
\end{aligned}
$$

MASTER

\title{
IN-PILE MECHANICAL FAILURE OF MTR FUEL ASSEMBLIES
}

\section{J. Harrison}
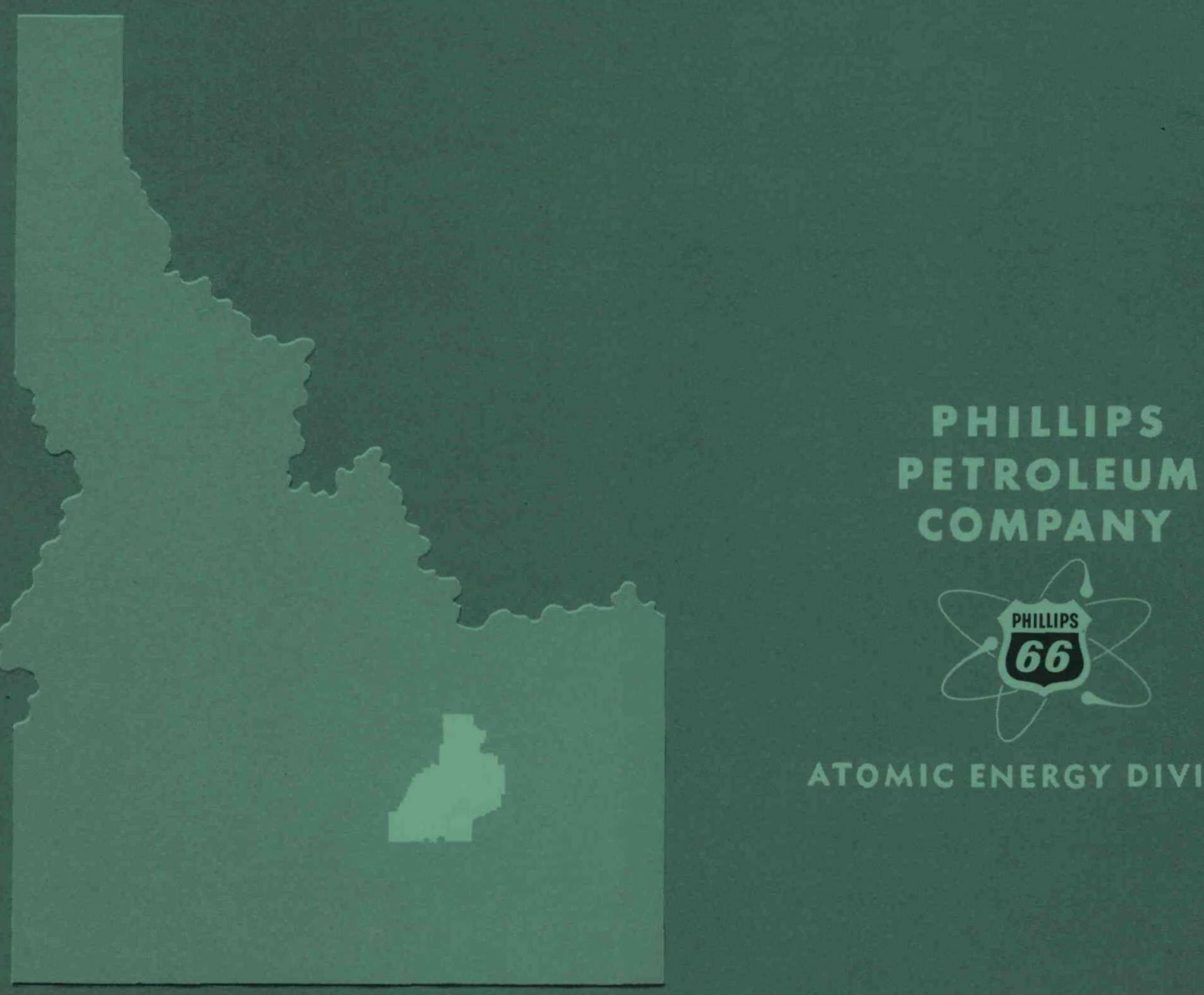

NATIONAL REACTOR TESTING STATION US ATOMIC ENERCY COMMISSION 


\section{PRICE $\$ 1.25$ \\ Available from the \\ Office of Technical Services \\ U.S. Department of Commerce \\ Washington 25, D. C.}

\section{LEGAL NOTICE}

This report was prepared as an account of Government sponsored work. Neither the United States, nor the Commission, nor any person acting on behalf of the Commission:

A. Makes any warranty or representation, express or implied, with respect to the accuracy, completeness, or usefulness of the information contained in this report, or that the use of any information, apparatus, method, or process disclosed in this report may not infringe privately owned rights; or

B. Assumes any liabilities with respect to the use of, or for damages resulting from the use of any information, apparatus, method, or process disclosed in this report.

As used in the above, "person acting on behalf of the Commission" includes any employee or contractor of the Commission, or employee of such contractor, to the extent that such employee or contractor of the Commission, or employee of such contractor prepares, disseminates, or provides access to, any information pursuant to his employment or contract with the Commission, or his employment with such contractor. 


\section{DISCLAIMER}

This report was prepared as an account of work sponsored by an agency of the United States Government. Neither the United States Government nor any agency Thereof, nor any of their employees, makes any warranty, express or implied, or assumes any legal liability or responsibility for the accuracy, completeness, or usefulness of any information, apparatus, product, or process disclosed, or represents that its use would not infringe privately owned rights. Reference herein to any specific commercial product, process, or service by trade name, trademark, manufacturer, or otherwise does not necessarily constitute or imply its endorsement, recommendation, or favoring by the United States Government or any agency thereof. The views and opinions of authors expressed herein do not necessarily state or reflect those of the United States Government or any agency thereof. 


\section{DISCLAIMER}

Portions of this document may be illegible in electronic image products. Images are produced from the best available original document. 


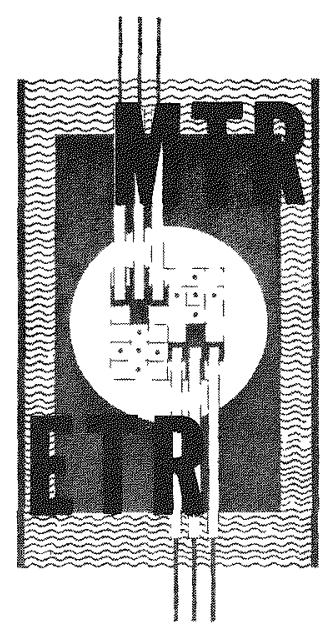

IDO-I6862

AEC Research and Development Report

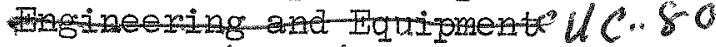
TID-4500 (20th Ed.)

Issued: JuIy 15, 1963

IN-PILE MECHANICAI FAILURE OF MTR FUEL ASSEMBIIES

By

L. J. Harrison

PHILLIPS

PETROLEUM

COMPANY

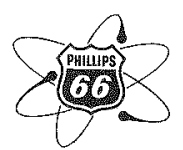

Afomic Energy Division

Contract AT(10-1)-205

Idaho Operations Office

U. S. ATOMIC ENERGY COMMISSION 

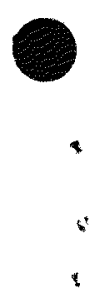

-

$\checkmark$

a

- 
The Materials Testing Reactor has been in operation eleven years. During this time three types of fuel assembly failures occurred during operation as the result of mechanical deficiencies of the assemblies. The first deficiency was the result of a design modification with the remaining two deficiencies the result of improper fabrication.

The first series of failures occurred in 1954 and were the result of a decrease in the flow area through the lower end box. This modification resulted in excessive lateral pressure acting on the outer concave fuel plate causing reversal of this fuel plate. These failures were the only ones of those under consideration which resulted in the release of fissile matexial and fission products. The deficiency was overcome by reestablishing the original flow axea and increasing the strength of the assembly.

The second series of failures occurred in 1960 and were the result of incomplete brazing of the fuel plates to the side plates. This greatly reduced the assembly strength resulting in gross fuel plate deformation. Assemblies fabricated via the pinning technique were utilized to overcome this deficiency.

The third series of railures occurred in 1961 and were the result of improper swaging of the side plates onto the fuel plates. This greatly reduced the assembly strength resulting in the side plates being bowed 
outward. This deficiency was overcome when the fabricator remestablished adequate quality control.

These experiences graphically show the need for a full evaluation of design changes and a high degree of fabrication quality control; also, the fuel purchaser must perform some acceptance tests. The acceptance tests carried out at MIR are presented. 


\section{$\underline{C} \underline{\mathbb{N}} \underline{T} \underline{\mathbb{N}} \underline{\underline{T}}$}

I. Introduction................. 7

II. In-Pile Failures................ 7

A. 1954 Brazed Assemblies.......... 7

B. 1960 Brazed Assemblies........... 10

1. Discovery of Fajlure........ 10

2. Hot Cel1 Inspection............ 12

3. Cause of Fulure..............21

4. Cycled Fuel Inspection....... 21

a. Inspection Procedure.....21

b. Inspection Results.......22

c. Failure Distribution..... 23

5. Monitor Tube Dota........... 25

a. Monitor Tube Description. 25

b. Thermocouple Data.......25

c. Pitot Tube Data.......... 28

6. Operation Preceutions........ 28

a. Overall Program.......... 28

b. Hydraulic Test Program... 31

(1) General Program..... 3I

(2) Fajlure Examination. 32

7. Long-Term Solution.......... 33

C. 1961 Roll-Swaged Assemblies..... 35

1. First Failure.............35

a. Discovery of Failure.... 35

b. Cause of Failure......... 38

c. Time of Fuilure......... 39

d. Reactor Instrumentation

Behavior............ 39

2. Second Failure.............. 41

a. Discovery of Failure..... 41

b. Cause of Failure.........4

3. Operational Precautions...... 42

2. Reactor Instrumentation

Surveillance..........42

b. Hydraulic Test Program... 42

c. Cycled Fuel Inspection... 44

4. Long-I'erm Solution.......... 44

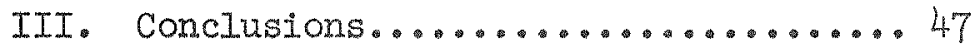

Acknowledgment.................... 48

References......................49 


\section{$\underline{F} \underline{I} \underline{U} \underline{R} \underline{E} \underline{S}$}

FIGURE 1 - Fuel Assembly..................... 8

FIGURE 2 - Reactor Internals Top Plan............... 12

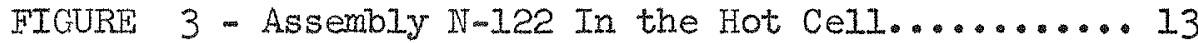

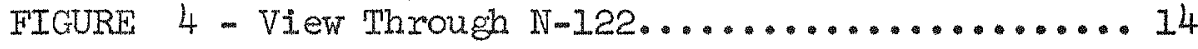

FIGURE 5 - IN-122 Sectioned Into Seven segments....... I5

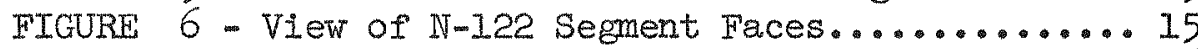

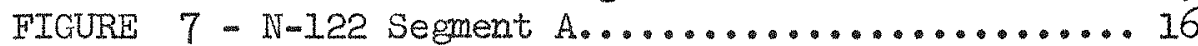

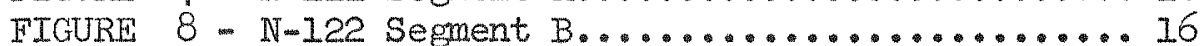

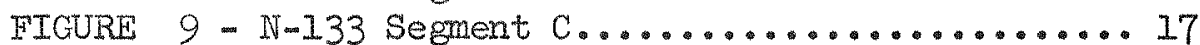

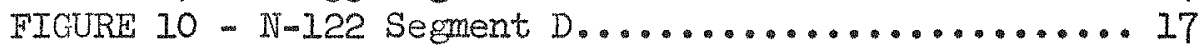

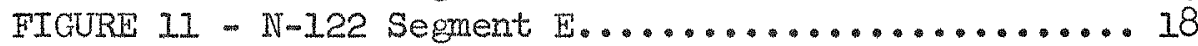

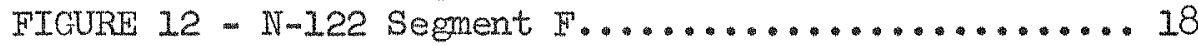

FIGURE 13 - Segment C With Three Plates Removed....... 19

FICURE 14 - Fuel Plate From Segment C................20

FIGURE 15 - Fuel Plate From Segment C................20

FIGURE 16 - Operating Positions of Brazed

Fuel Assemblies Which Failed............ 24

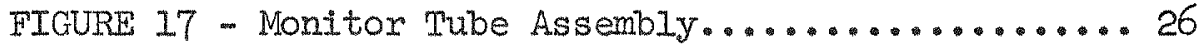

FIGURE 18 - Monitor Tube Data Indicating

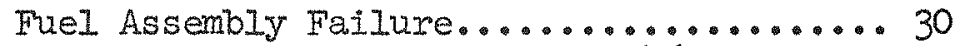

FIGURE 19 - Segment of Failed Assembly N-146........ 32

FIGURE 20 - Unbrazed Plates Displaced From

Failed Segment..................... 33

FIGURE 21 - Assembly J-61 With Bowed Side Plate...... 36

FICURE 22 - J-61 With North Side Plate Removed....... 37

FIGURE 23 - Proper and Improper Swaging............. 38

FIGURE 24 - Servo Preamplifier output.............. 40

FICURE 25 - Roll-Swaged AssembIy - Hyaraulic

Test Failure.......................... 44

$\underline{I} \underline{B} \underline{I} \underline{E} \underline{S}$

TABLE I - Core Operating Conditions.............. 9

TABLE 2 - Typical NPR Core Monitor

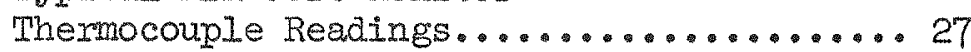

TABLE 3 - Typical MIR Core Pitot Tube Data......... 29 


\section{Introduction}

The MTR fuel assembly has served as a basic model for a number of other fuel assemblies. Consequently tne operating experience of the MTR fuel assembly is directly applicable to certain other reactors. This experience is applicable to all types of reactor fuel assemblies in a general manner.

A particular phase of operating experience is presented herein. This phase is the in-pile failure of assemblies due to mechanical deficiencies of the assemblies. The discovery, cause and solution to the various deficiencies are presented. Of particular interest will be the source of the failures and the steps taken to avoid additional failures. These will be of interest not only to the reactor operator but also to the fuel designer and fuel fabricator.

\section{In-Pile Failures}

\section{A. 1954 Brazed Assemblies}

The 1954 brazed fuel assembly failures are well documented in the literature $(1,2,3,4)$. These failures are briefly discussed in this report for subjective continuity. The interested reader is referred to the literature.

After the MIR had been operating successfully for some two years, the release of fissile material and fission products into the primary coolant was detected. This release was traced to cladding ruptures which had occurred in the outer fuel plates of a number of assemblies. Figure I presents a view of an assembly. The outer concave fuel plates were being partially reversed resulting in decreased thickness of the coolant channel between the outer concave and the outer convex fuel plates 


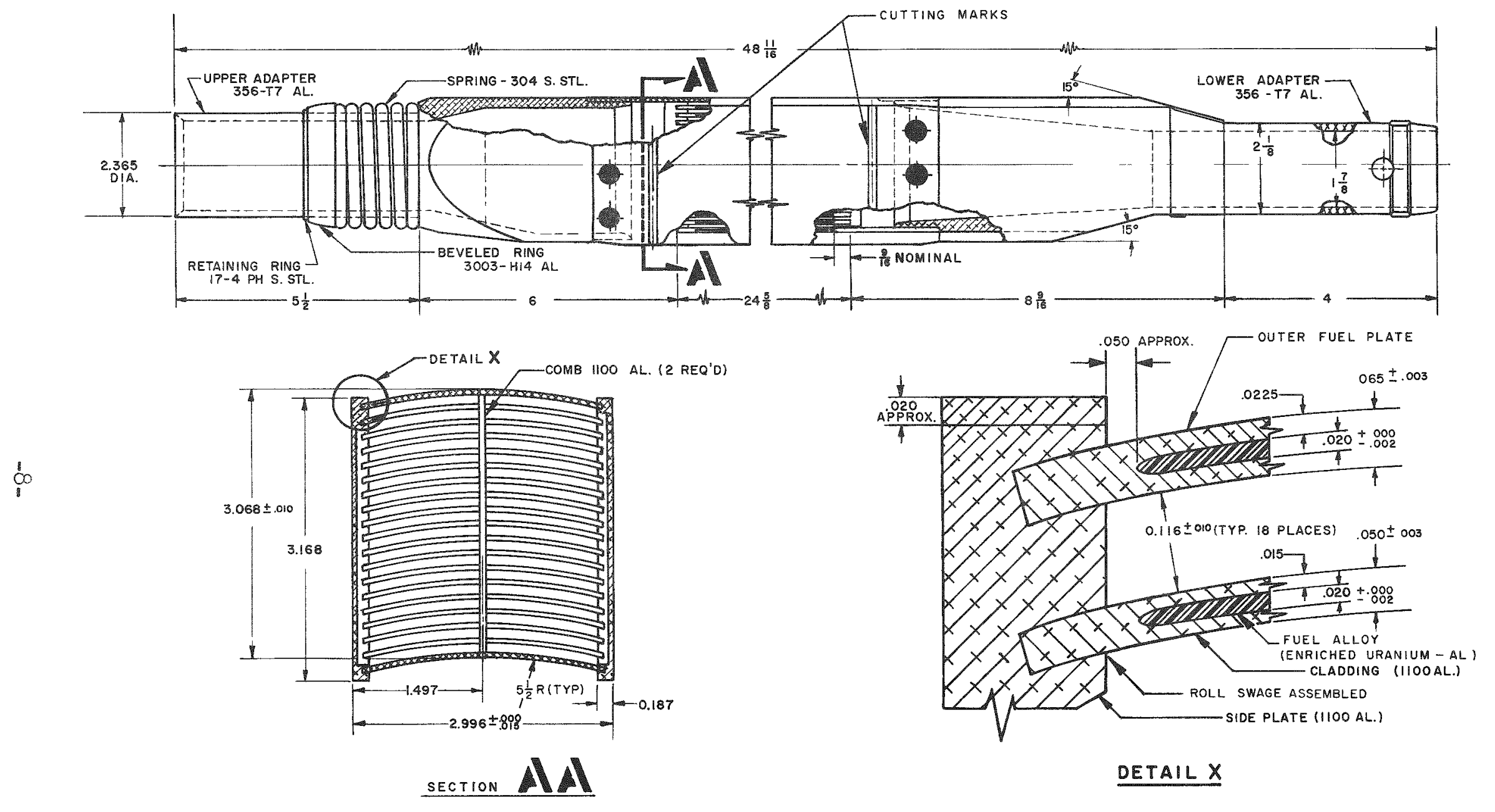

PPCo-c- - 2816

FICURE 1 - Fuel AssembIy 
of adjacent assemblies. The decreased channel thickness resulted in higher fuel plate surface temperatures which in turm resulted in corrosion erosion and rupture of the cladding. Table 1 presents the core operating conditions.

TABLE 1

Core Operating Conditions

Coolant...............Demineralized Water

Core pressure differential, psi....... 40

Flow in one fuel assembly, gpm....... 650

Average velocity, fps.............. 33

Flow in one control rod, gpm.......... 550

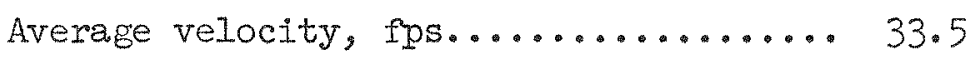

Reactor inlet temp., F............. 105

Reactor outlet temp., ${ }_{\mathrm{F}} \ldots \ldots \ldots \ldots \ldots \ldots$

Avg. heat $f l u x, B I U / h r-f t^{2} \ldots \ldots \ldots . . . .3 \times 10^{5}$

Max. heat flux, BTU/hr-ft ${ }^{2} \ldots \ldots \ldots . . . .3 \times 10^{5}$

Burnout heat flux, BTU/hrmet ${ }^{2} \ldots \ldots \ldots 19 \times 10^{5}$

Max. fuel plate surface temp., ${ }$ F...... 310

To determine the cause of the concave plate reversals, in-pile hydraulic measurements were conducted. These measurements revealed an extrene increase in the lateral pressure differentials acting across the outer fuel plates since the reactor had gone critical. Out-of-pile tests showed the higher lateral differentials to be of sufficient magnitude to cause the plate reversals.

It was subsequenty determined that the increased lateral pressure differentials were the result of a minor modification of the lower end boxes. Difficulties were being encountered in the casting of 
the lower end boxes. To overcome the difficulties, the thickness of the end box walls was increased. This increase resulted in the internal. cross-sectional area of the end boxes being decreased from 3.7 in. $^{2}$ to 3.2 in. ${ }^{2}$. It was this seemingly insignificant change which resulted in the in-pile failure of a number of assemblies.

The fuel assembly failures were overcome by three modifications to the assembly: (1) the internal cross-sectional area of the end box was increased from $3.2 \mathrm{in}^{2}$ to $3.7 \mathrm{in}^{2}$, (2) the thickness of the two outer fuel plates was increased from $0.050 \mathrm{in.} \mathrm{to} 0.065 \mathrm{in.,} \mathrm{(3)} \mathrm{the}$ thickness of the side plates was increased from 0.110 in. to 0.187 in. The latter two modifications were effected to increase the mechanical strength of the assembly.

\section{B. 1960 Brazed Assembly Failure}

\section{Discovery of Failure}

When the graveyard shift came on duty at $0000 \mathrm{hr}$, July 5 , 1960, the MTR was shutdown. The reactor had been scrammed earlier due to a commercial power failuxe. The preceeding shift had refueled the reactor with a mixed loading composed mainly of fuel assemblies being recycled together with a few new fuel assemblies. The reactor was ready for reinsertion of the upper grid plate and re-emplacement of the reactor top head.

Upon completion of these two items, reactor startup commenced with the normal startup procedure being followed. Included in this procedure was the setting of the alarm points for the pitot tube readings obtained from the core fuel assembly monitor tubes. These alarm points were set at plus and minus 2 psi from the normal pitot tube readings which range from 13.4 to 15.5 psi. 
Shortly thereafter a power level of $7 \mathrm{MW}$ was attained closely followed by a Fuel Element Flow annunciation indicating a low coolant flow at one of the pitot tubes. The annunciator sounded approximately 15 minutes after the setpoints had been established. The annunciator was cleared, presumably by lowering the setpoint, and the reactor power was raised to $20 \mathrm{MW}$ with this power level maintained for two hours. At the end of this period the reactor power was increased in a series of small steps going towards the normal full power of $40 \mathrm{MW}$. Immediately following the 33 to $36 \mathrm{MW}$ step, a Fuel Element Water Temperature annunciator sounded. This annunciator indicated a high monitor tube temperature differential. The monitor tube temperature differential is the fuel assembly outlet coolant temperature as measured by the monitor tubes minus the bulk reactor coolant outlet temperature. The 25 individual temperature differentials are indicated on two miltipoint recorders with the setpoint two degrees above the maximum reading.

Investigation of this second annunciator by the shift supervisor and canal operator revealed the source to be core position I-38. Figure 2 presents the reactor internals top plan. This position also was the source of the first annunciator. At the time of the investigation the temperature differential was $14.8^{\circ} \mathrm{F}$ and the pitot tube reading was varying between 7 and 10 psi.

At this point a nanual fast setback was effected followed. by a manual scram when the power level had reached $N_{L^{-}}$. The reactor top head was removed and the fuel assembly in position L-38, N-122, was examined. This cursory examination found the fuel plates in the assembly to be severly deformed. The assembly was then aischarged to the canal with a new assembly replacing it in the reactor. 


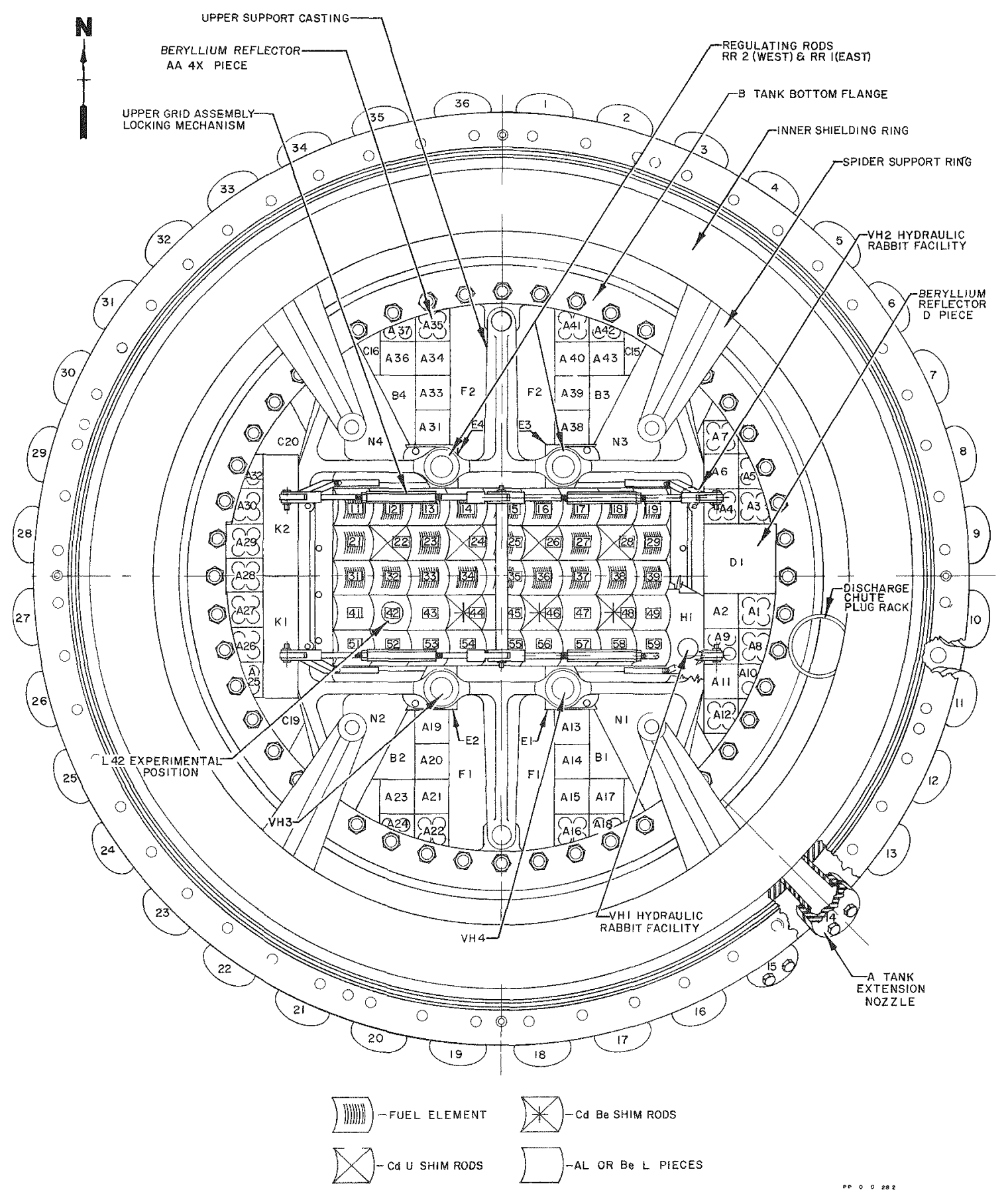

FIGURE 2 - Reactor Internals Top Plan

\section{Hot Cel1 Inspection}

The damaged fuel assembly remained in the MTR canal over the weekend and, following the removal of the assembly end boxes, was transported via a dry cask to the MTR-ETR Hot CeII. The normal procedure 
for hot cell examination of MTR and ETR fuel assemblies required the fission product decay heat flux to be below the operating heat flux by $a_{0}$ factor of approximately $10^{4}$. Since this assembly had operated in the core for only a short period of time, the required heat flux was attained in approximately 30 hours. When the assembly was transferred from the cask to the cell, there were arops of water remaining in the fuel channels indicating moderate assembly temperature.

Figure 3 is a photograph of $\mathbb{N}-122$ as it entered the hot cell. The discolorization of the upper concave fuel plate outlines the fuel core of the fuel plate. The dark discolorization normally occurs at the upper end with the lighter discolorization occurring at the lower end of the fuel plates where the surface temperature is higher. Figure 4 presents the view through the coolant channels looking at a spotlight.

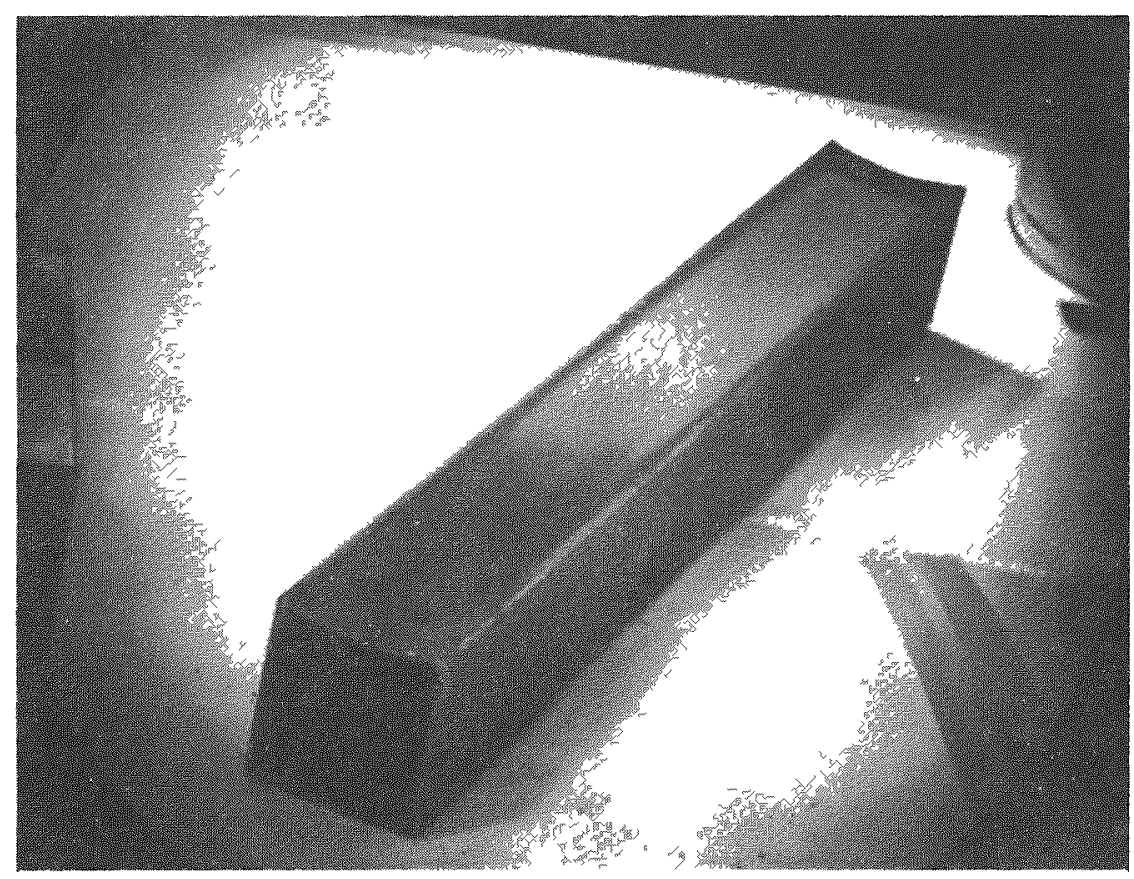

FICURE 3 - AssembIy N-122 In The Hot Cel1 


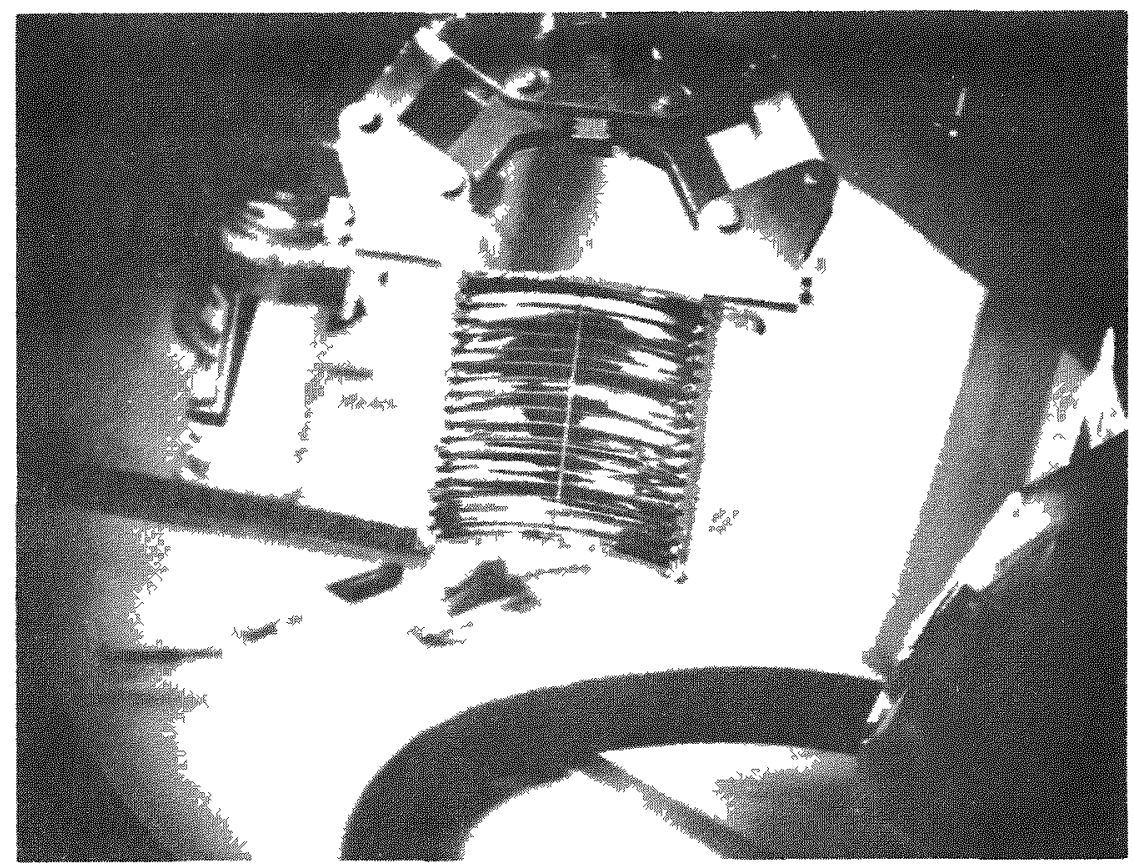

FICURE 4 - View Through $\mathbb{N}-122$

The obliteration of light in the center of the assembly was due entirely to the deformed fuel plates and not to the presence of any foreign material. One channel near the upper convex plate presents the normal appearance of the channels. The upper convex plate had been flattened at one end of the assembly while being handed after the end boxes had been removed. To ascertain the cause of the plate buckling, the assembly was traversly sectioned into seven segments as show in Figure 5. The marking on the side plate is a reference line. The first five segments were each $2 \mathrm{in.}$. In length and the remaining two segments were each 14 in. in length. Figure 6 presents a face view of the seven segments labeled. A through $G$ beginning at the upper end of assembly. Figures 7, 0,9 , 10, II and 12 present close up views of the faces of segments A through $F$, respectively, show in Figure 6. The cutting burrs became progressively larger as segments were cut. 


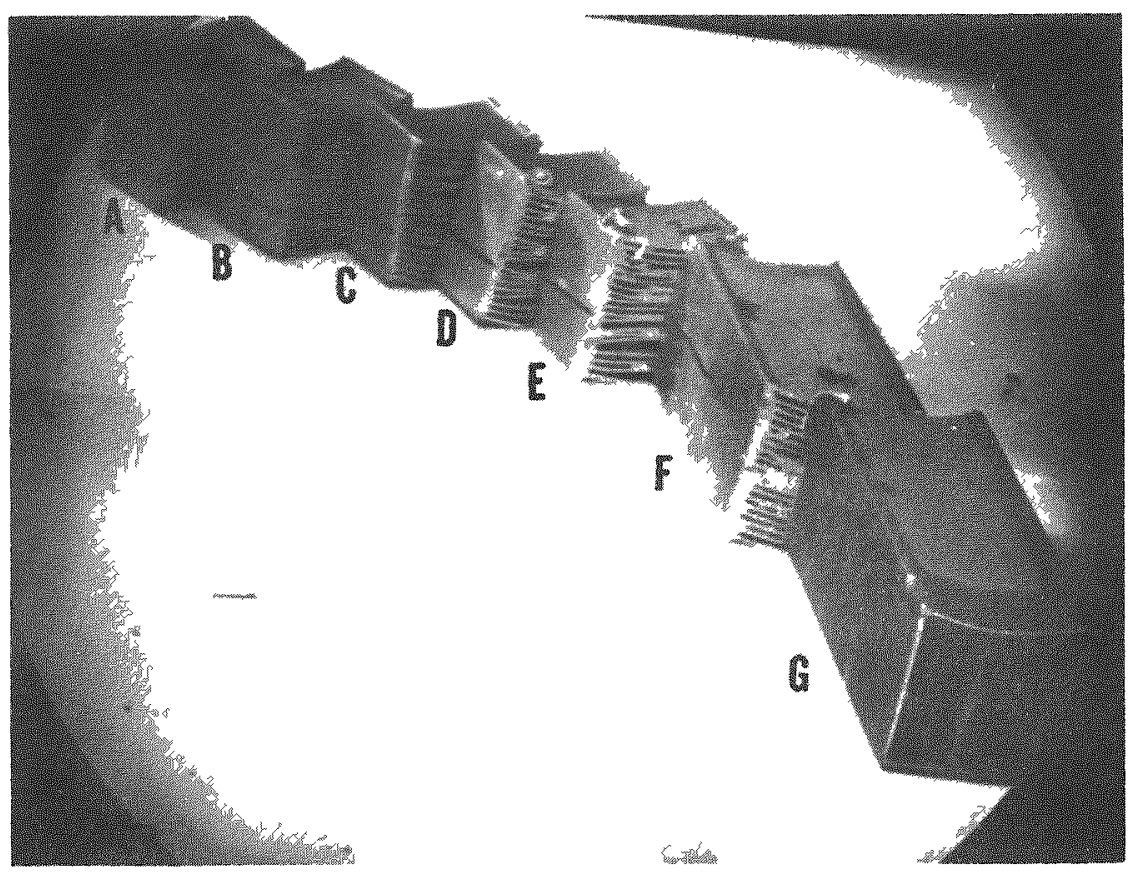

FIGURE 5 - N-122 Sectioned Into Seven Segments

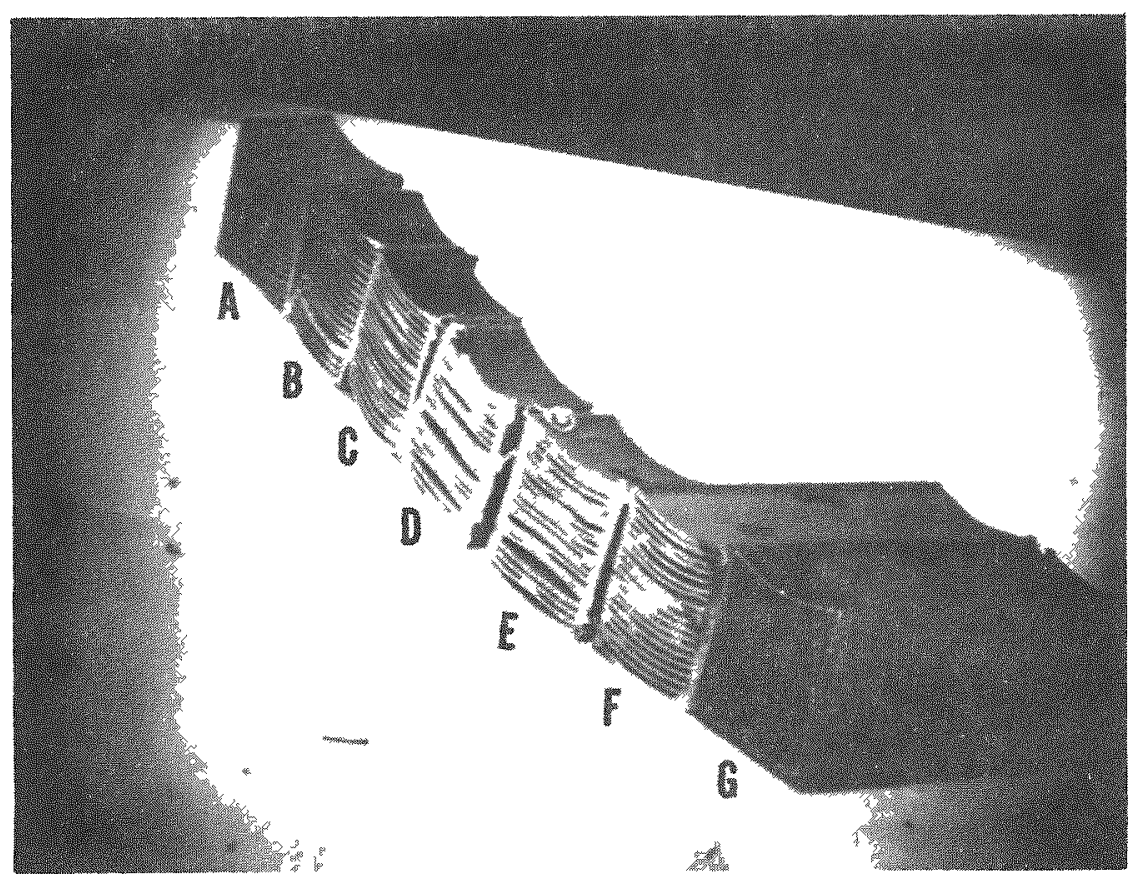

FIGURE 6 - View of $\mathrm{N}-122$ Segment Faces 


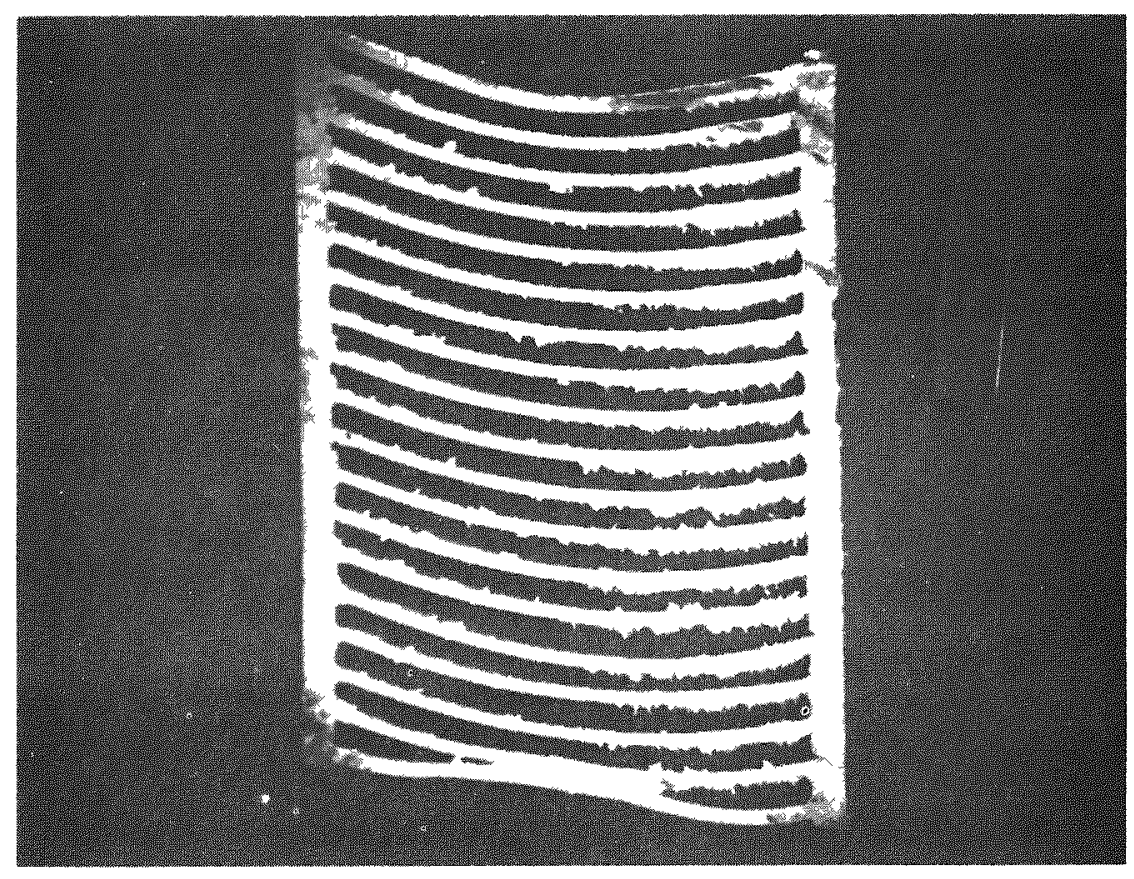

FIGURE $7-N-122$ Segment A

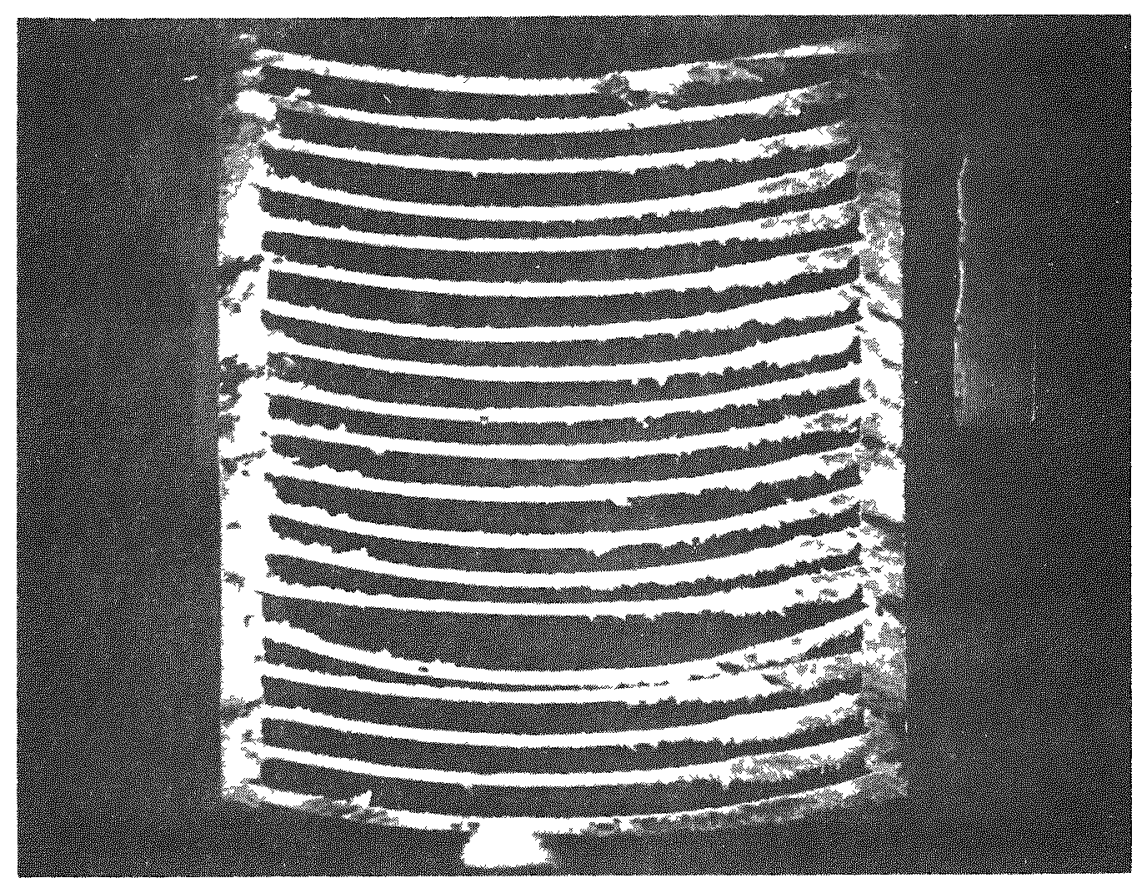

FIGURE 8 - N-122 Segment B 


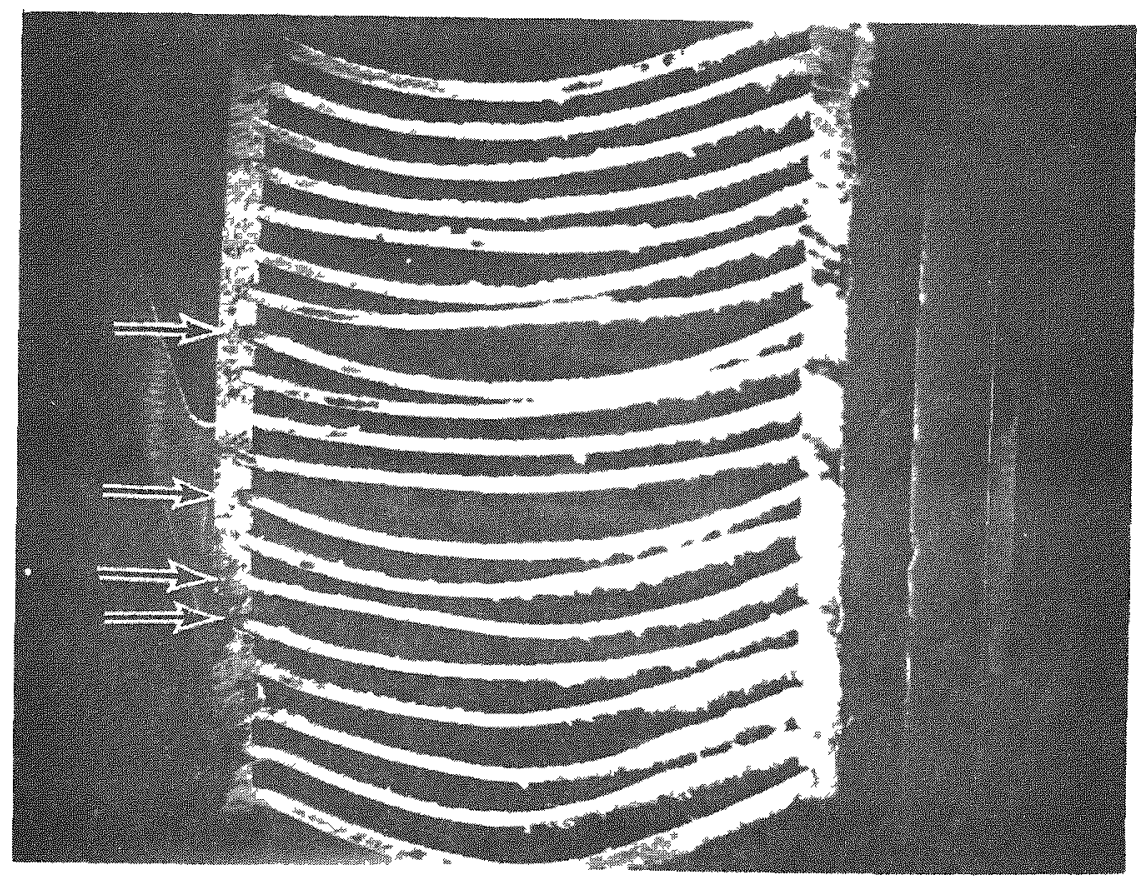

FICURE 9 - N-122 Segment C

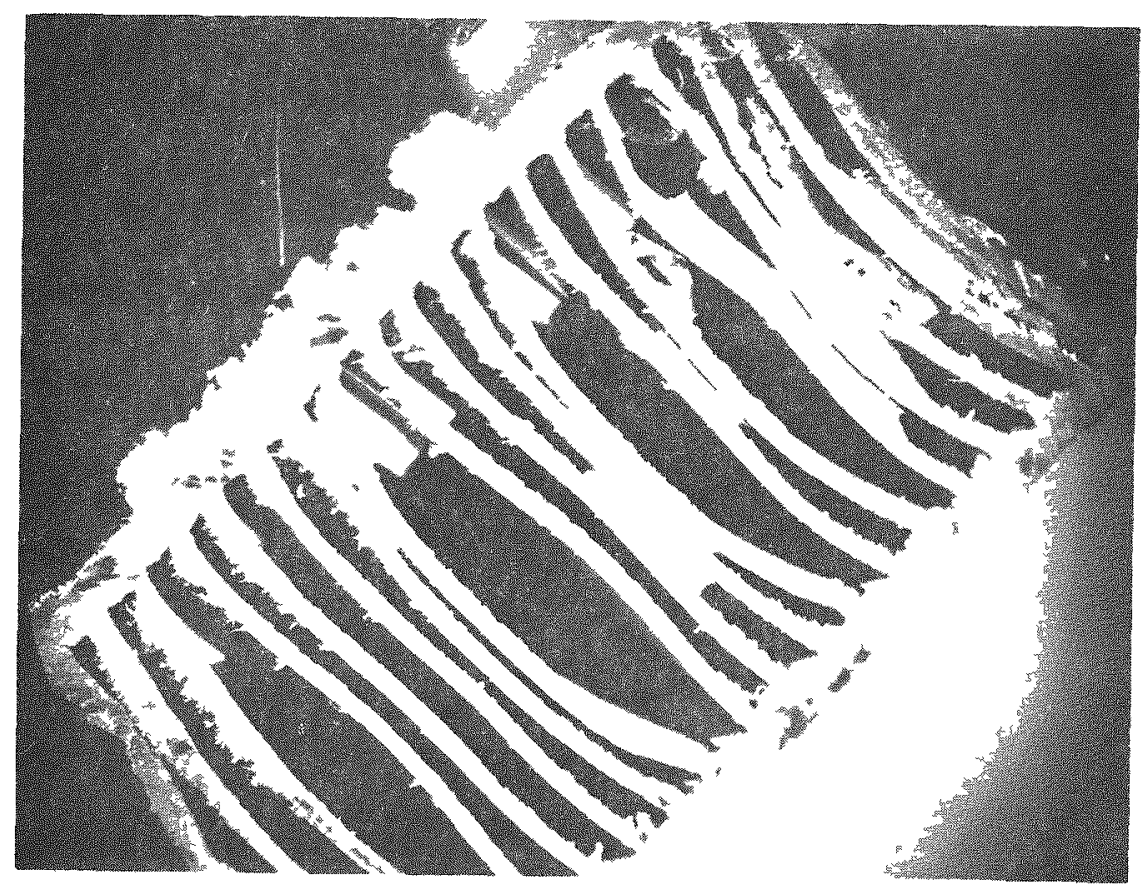

FTGURE 10 - N-122 Segment D 


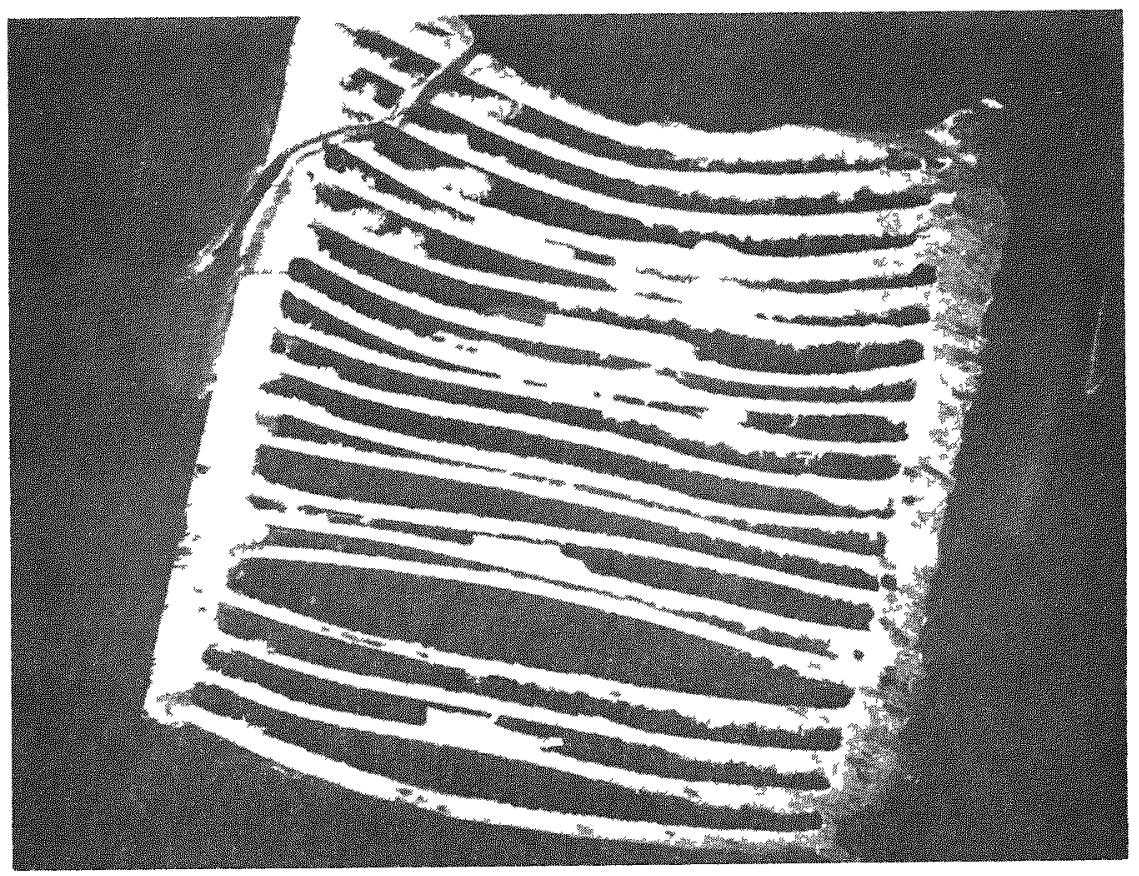

FIGURE 11 - N-122 Segment $E$

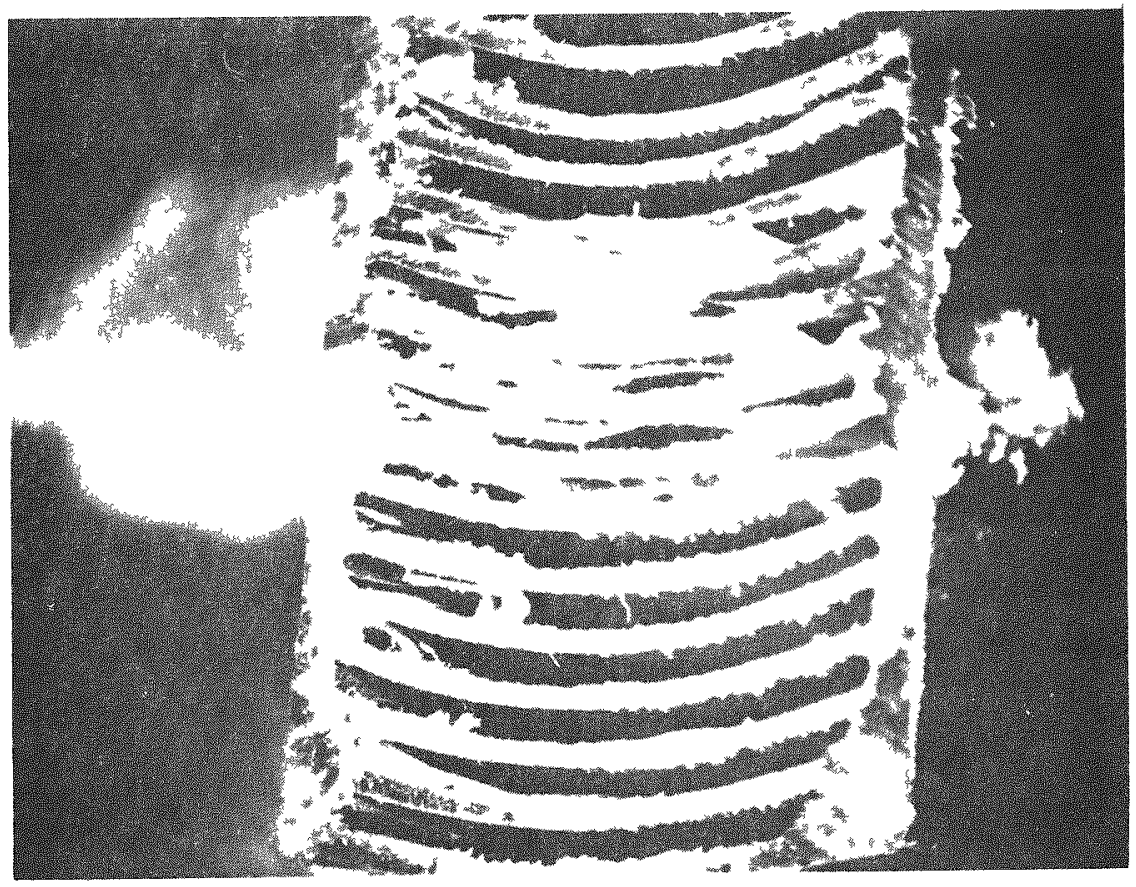

FIGURE 12 - N-I22 Segment F 
To remove the cutting burrs, both faces of each segment were polished on emery paper. Each segment was then water washed to remove any loose metal particles remaining in the segnent. As the water residue was being shaken from segment $C$, it was noted that four of the plates were free and beginning to fall out of the segment. As shown in Figure 13, three of the four plates were easily removed while the fourth plate was only partially displaced. The end of segment $\mathrm{C}$ prem sented in Figure 13 is the opposite end from that presented in Figure 9.

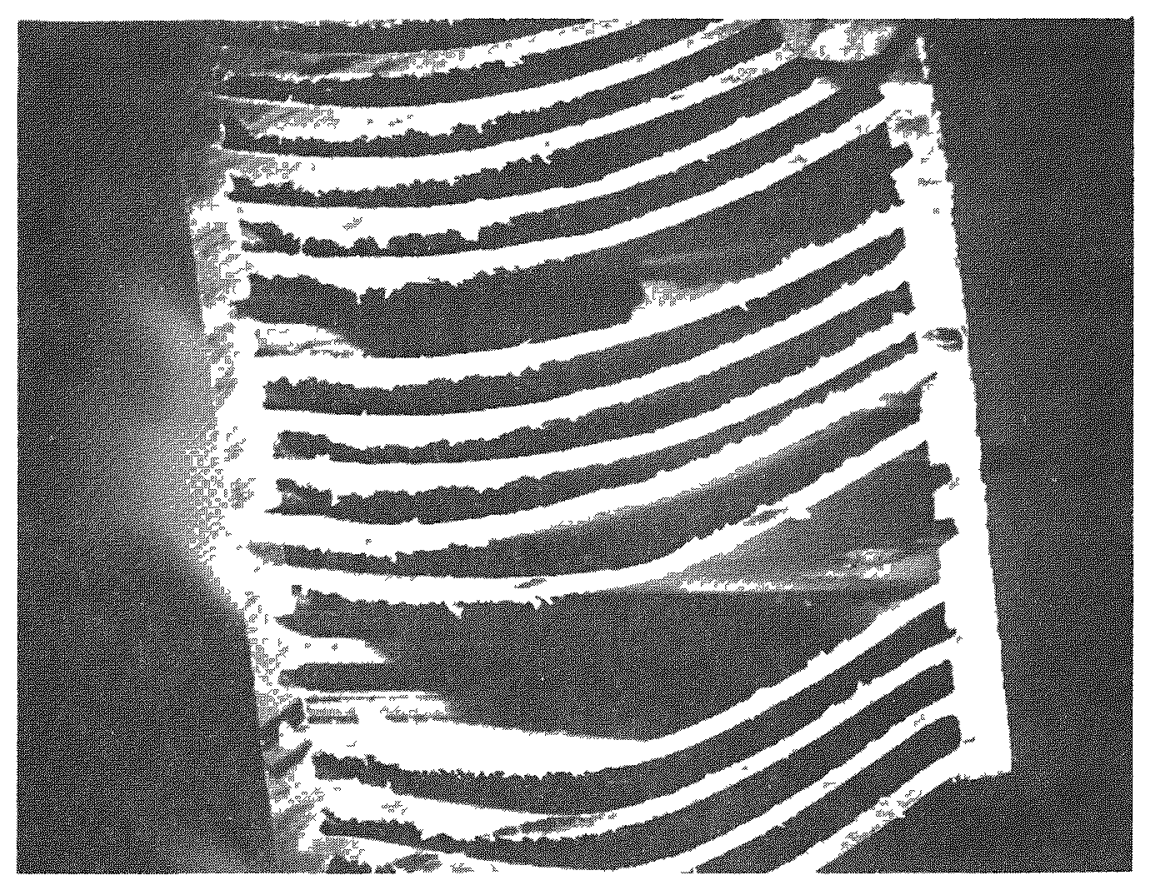

\section{FICURE I3 - Segment C With Three Plates Removed}

Figures 14 and 15 present photographs of two of the plates which were removed from segnent $C$. Both of these plates exhibit local areas of gross discolorization indicating both plates had experienced high surface temperatures. This is quite reasonable in light of the 


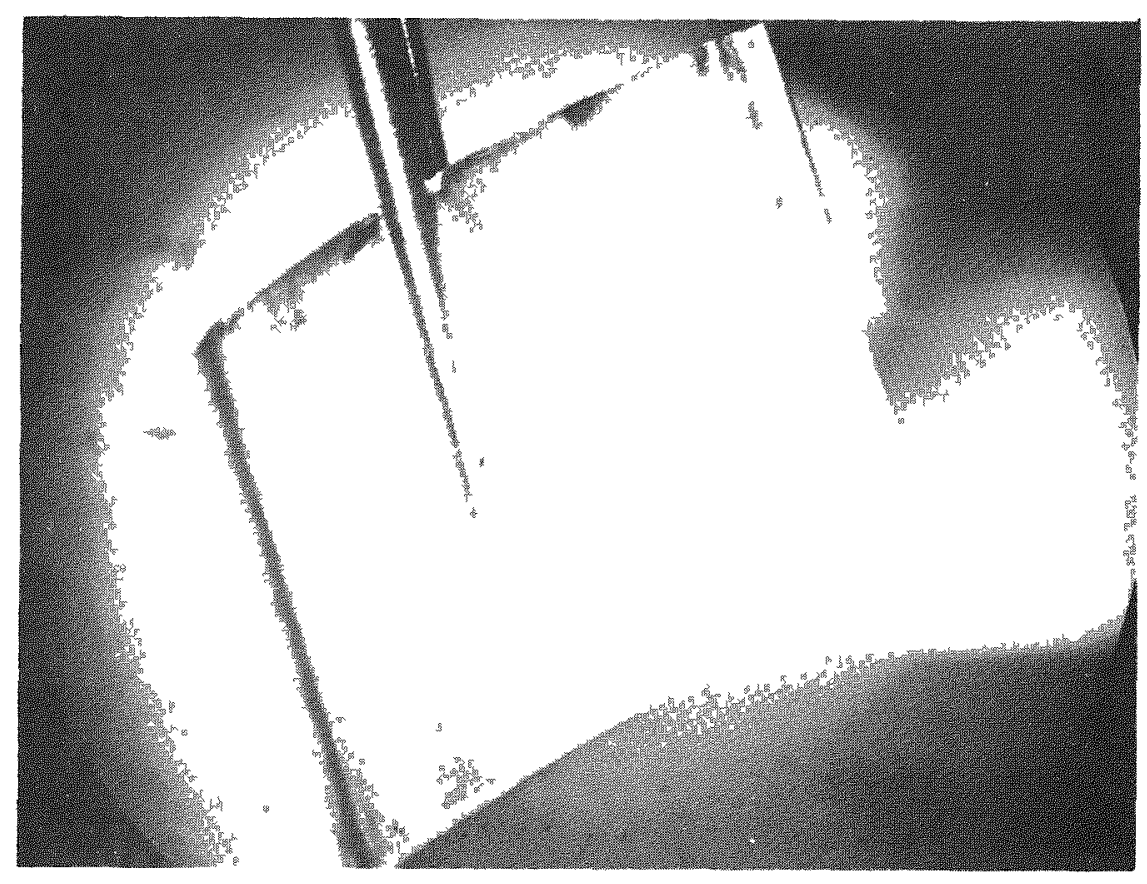

FIGURE 14 - Fuel Plate From segment C

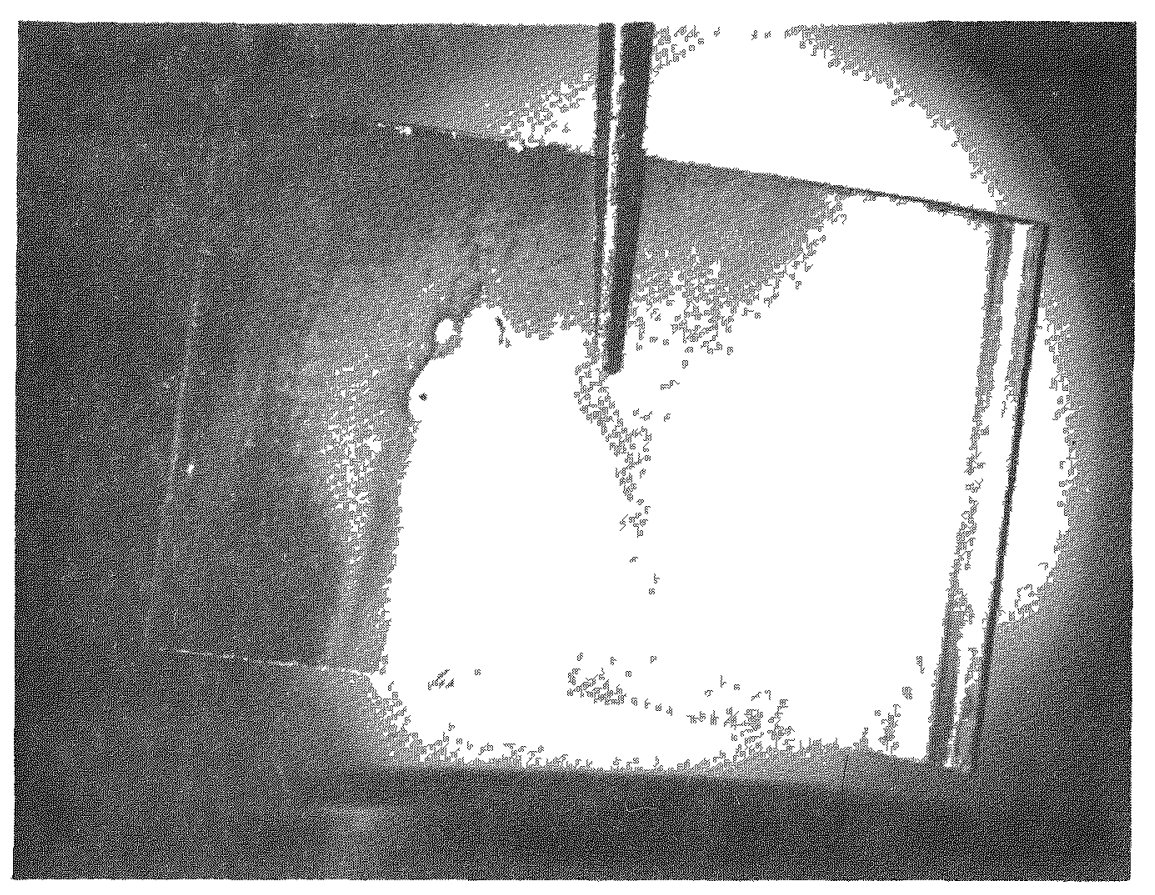

FTCURE 15 - Fuel Plate From Segment C 
proximity of the distorted fuel plates. No analysis was performed to determine the nature or source of the small black spots evident on some of the fuel plates. It should be noted, however, that there was no evidence to indicate a mupture of the cladding or a metal-water reaction.

\section{Cause of Failure}

The cause of the fallure was obvious from segment $C$. The brazing process had failed to establish a contimuous bond between the fuel plates and the side plates resulting in an assembly of significantIy reduced strength. Examination of Figure 9 in particular reveals that many of the fuel plate - side plates joints are not bonded together. The unbonded lengths were obviously in excess of two inches at a number of locations.

The lateral pressure differentials which have been measured across the MTR fuel plates were apparently of sufficient magnitude to initiate the deformation of the unbonded fuel plate. Once the deformation had been initiated the redistribution of forces in accordance with the Bernoulli equation would tend to magnify the lateral pressure differentials. The plate deformation would continue until an equilibrium geometry was established.

An idea of the longitudinal deformation profile can be obtained from Figures 5 and 6.

Additional discussion of this matter is presented in

Section 6. a. (2).

4. Cycled Fuel Inspection

a. Inspection Procedure

To determine whether the failure of $N-122$ was an isolated failure or whether the fabricator's process was out of control, 
all of the cycled fuel assemblies in the canal were inspected. Each of these assemblies had been in the reactor for one or more cycles but the fuel content of most assemblies was still at a sufficient level tc permit additional recycling in the reactor. A few assemblies, however, had completed their reactor service and were awaiting shipment to the Chemical Processing Plant.

The following procedure was used to inspect fuel assemblies in the canal: An assembly was removed from its fuel storage rack using a hook-tool and held a few feet above the stainless steel canaI floor. The assembly was positioned so that a strong beam of light reflected off the canal floor shone through the assembly. The inspector, viewing the assembly through approximately 15 feet of water, saw the assenbly approximately as shown in Figure 4. The view through the fuel assembly was restricted by the 2 in. I.D. upper end box. Each normal fuel plate was seen as a black, well defined arc. Each deformed plate was seen as a poorly defined arc when the deformation was minor and as a thick, black, nondescript object, as in Figure 4, when the deformation was severe.

\section{b. Inspection Results}

A total of 127 cycled fuel assemblies was in the canal at the time of the inspection. Of these, seventy elght were $\mathbb{N}$ series assemblies from the current fabricator, thirty seven were $C$ series assemblies from the previous fabricator and the remaining twelve were experimental plutonium $X$ series assemblies. The inspection found eighteen $\mathbb{N}$ series assemblies, two $C$ series assemblies and no $X$ series assemblies which had deformed fuel plates. 
Assuming these inspection results to be representative of all the assemblies from the particular fabricators, six additional $N$ series assemblies and fourteen additional $\mathrm{C}$ series assemblies had failed in the reactor and had been sent to the Chemical Processing Plant with the failures not detected.

The fraction of assemblies which failed in service may well have been higher than the inspection results indicated. This is due to several of the fuel plates being hidden by the end boxes, resulting in the possibility of undetected plate failures.

The degree of failure in $N-122$ was more severe than in any of the other failures noted in canal inspection. In most cases there appeared to be two or three plates which were deformed.

To prevent recycling of the damaged assemblies, the end boxes were cut off aII such assemblies and the assemblies were shipped to the Chemical Processing Plant.

\section{c. Failure Distribution}

A study was performed to evaluate the possibility of some uninown reactor characteristic contributing to the fuel assembly failure. This study entailed a review of the cycle history of each failed assembly. From this review a determination was made as to the number of reactor cycles the various core positions contained one of the assemblies under consideration. The results of this study are presented in the core map in Figure 16.

From this map it can be seen that the positions occupied by the deficient assemblies are fairly evenly distributed with the exception of position L-21. The first impression is that this position inherently tends to fail fuel assemblies. There are, however, facts 


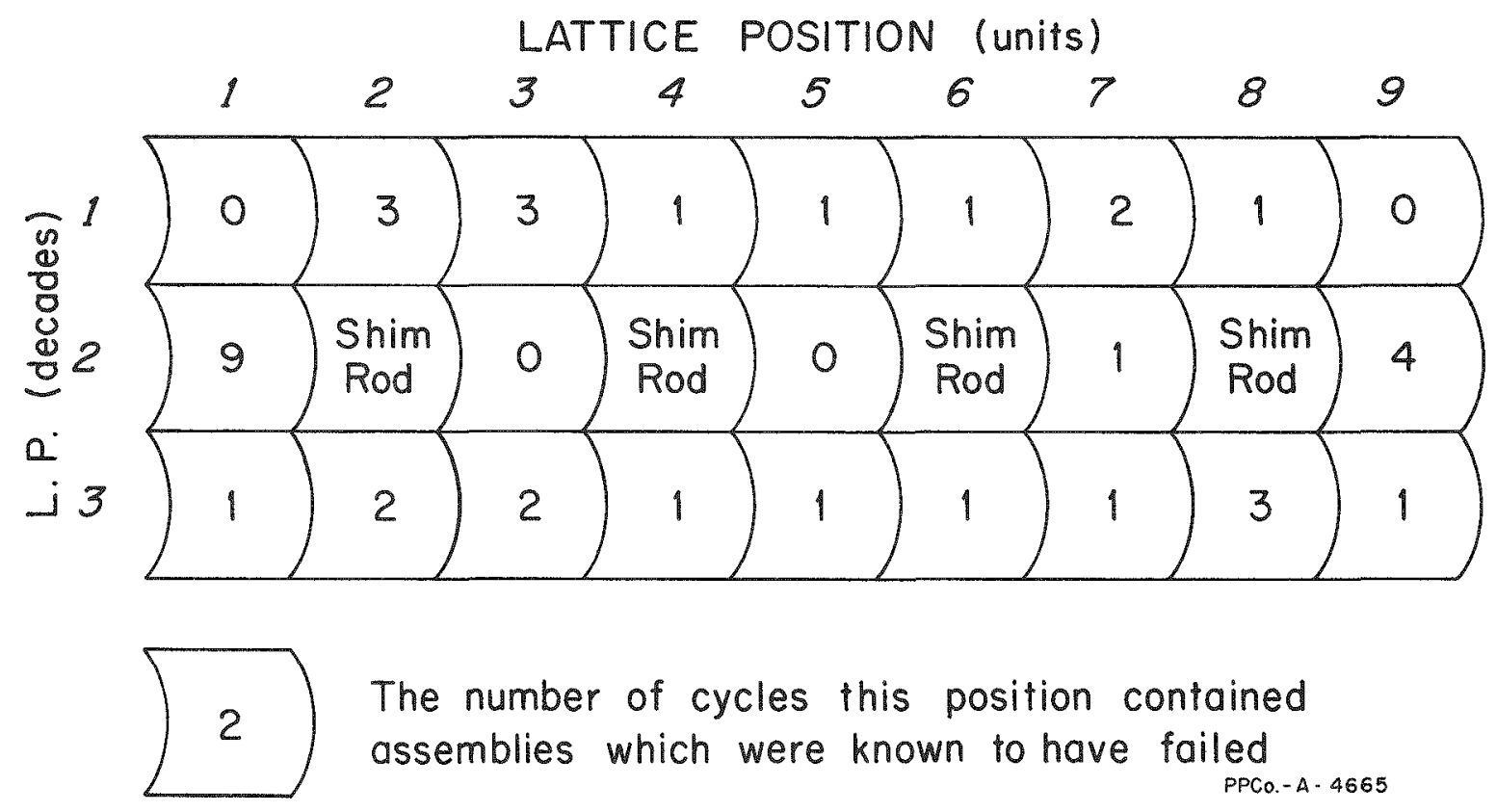

FIGURE 16 - Operating Positions of Brazed Fuel Assemblies Which Failed

which counter this impression. (1) The most severe fajlure occurred in position L-38 rather than position L-21. (2) There are two factors which weight the high value: (a) new assemblies are normally inserted initially in the outer positions and then recycled in the inner positions, and (b) one assembly experienced four successive short cycles in position L-al and another assembly experienced two successive cycles in this position. (c) the previous in-pile failures were found to be independent of core position. Thus it can be concluded that the failures are a function of the assemblies themselves and are independent of reactor position.

The average number of cycles experienced by each of the deformed assemblies was two. Thus it is not know definitely whether 
a particular assembly failed before, during or after it had operated in a particular position. In a few instances, however, the monitor pitot tube readings revealed the failures.

5. Monitor Tube Data

\section{a. Monitor Tube Description}

The monitor tube system is designed to obtain operating data from each of the fuel assemblies. Each monitor tube, as shown in Figure 17, is screwed into the reactor bottom head with its tip end extending up into the lower end of one of the assemblies. Each monitor tube contains four lines which are:(1) static pressure impulse line, (2) dynamic pressure impulse line, (3) thermocouple line, and (4) water sample line. The static and dynamic pressure lines are run to differential pressure cells to measure the coolant velocity head in the end boxes. The thermocouple lines are run to one of two multipoint recorders. These recorders indicate the difference between coolant temperature in the end boxes and the bulk coolant outlet temperature.

\section{b. Thermocouple Data}

Table 2 presents typical thermocouple data obtained during several cycles over a period of eight months. From this table it is obvious that the thermocouples in two positions were inoperative. Most of the remaining positions were obviously in error in that the measured values were in gross disagreement with the calculated values. The calculated temperature differentials range from $3.5^{\circ}$ to $8.5^{\circ} \mathrm{F}$ with $6.0^{\circ} \mathrm{F}$ being the average. With the majority of the thermocouples not functioning properly, the readings of the renaining thermocouples were questionable even though they fell within the correct range.

The thermocouples were sensitive to significant 


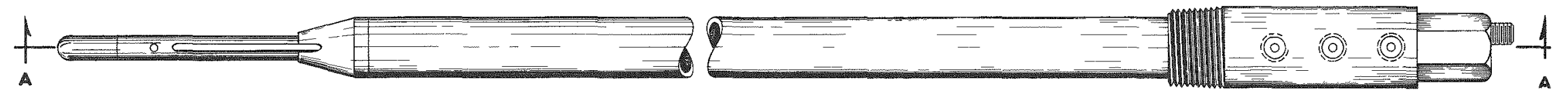

$\stackrel{1}{\circ}$

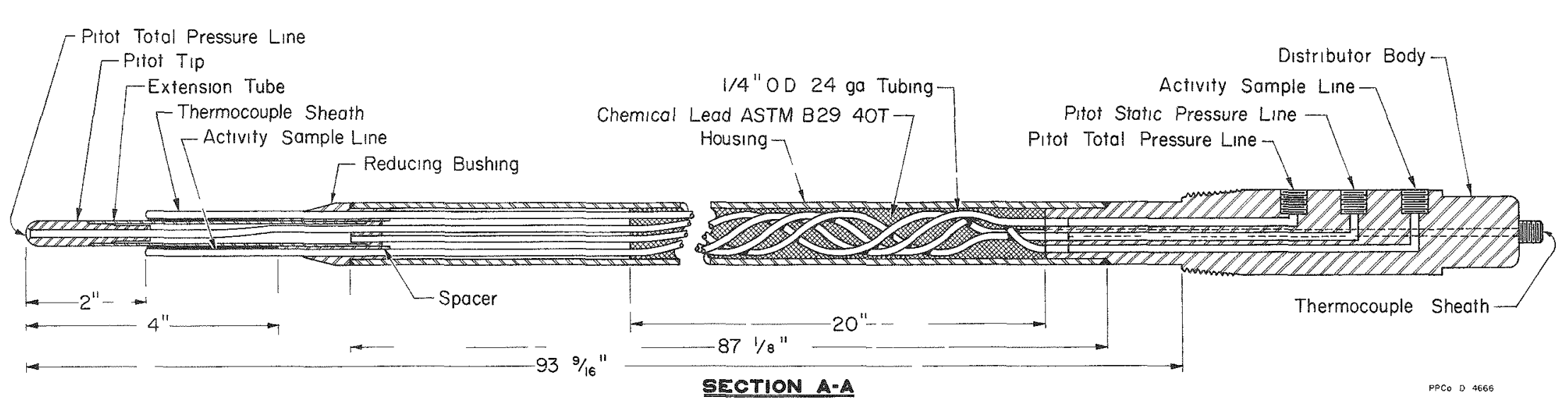

FICURE 17 - Monitor Tube AssembIy 


\section{TABLE 2}

TYPICAL MER CORE MONITOR THERMOCOUPLE READINGS

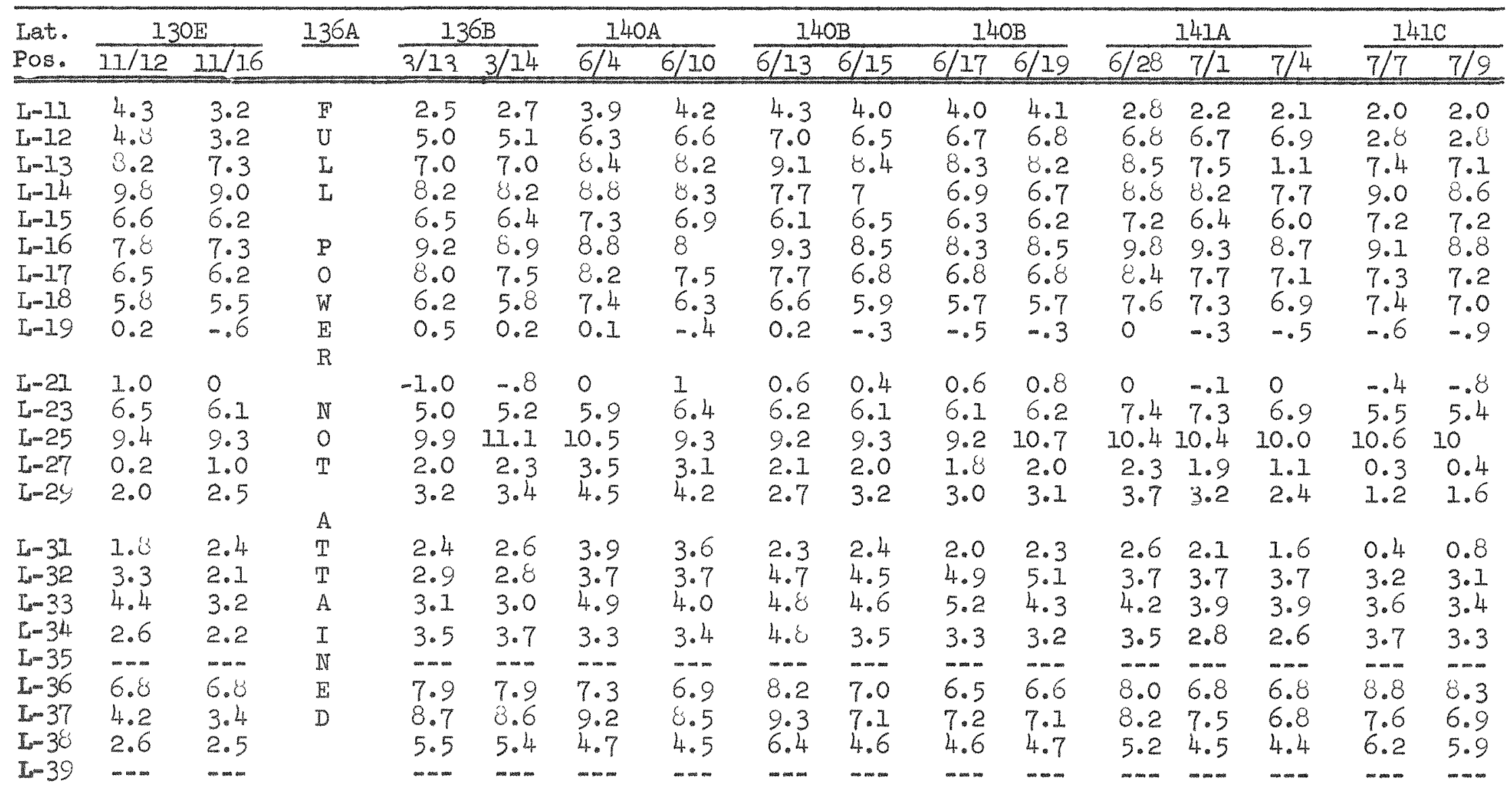


changes in the coolant outlet temperature as exemplified by the performance of the thermocouple in position $\mathrm{L}-38$ at the time of failure of assembly $\mathrm{N}-122$.

\section{c. Pitot Tube Data}

Table 3 presents typical pitot tube data obtained at the time of the failure of assembly $\mathrm{N}-122$ and during the two preceeding cycles. From this table it is obvious the pitot tubes in three positions were in gross disagreement with the remaining readings. The normal range of reading, 13.4 to 15.5 psi, were significantly below the calculated value of $19 \mathrm{psi}$. This deviation is attributable to the static pressure taps being located below the grid plate rather than in the end boxes resulting in a higher static pressure reading.

The pitot tubes were sensitive to significant changes in coolant flow rate as exemplified by the performance of the tube in position $I-38$ at the time of the fajlure of assembly $\mathbb{N}-122$.

A review was made of the pitot tube readings obtained from the positions which contain assemblies which had failed. This review showed that the pitot tubes had indicated a decrease in flow through the assembly in a number of cases. Figure 18 graphically presents the data which revealed the failure of an assembly. In general It appeared that a gross failure or the failure of a few central fuel plates could be detected whereas the failure of a few outer fuel plates could not be detected.

\section{Operational Precautions}

\section{a. OveralI Program}

Irmediately upon the discovery of the failure of assembly $N-122$, the status of the fuel assemblies was reviewed by Operations, 
TABLE 3

TYPICAL MTR CORE PITOT TUBE DATA

\begin{tabular}{|c|c|c|c|c|c|c|c|c|}
\hline & Cycle No. & \multicolumn{4}{|c|}{$140 B$} & \multicolumn{2}{|c|}{$141 \mathrm{~A}$} & $141 \mathrm{~B}$ \\
\hline & $L=12$ & 14.2 & 14.3 & 14.5 & 14.6 & 13.7 & 14.1 & 13.2 \\
\hline & $\operatorname{In} 13$ & 13.0 & 13.0 & 13.0 & 13.1 & 12.4 & 13.5 & 13.0 \\
\hline & $I=14$ & 8.8 & 8.9 & 9.0 & 9.0 & 7.2 & 8.2 & 8.0 \\
\hline T & $\operatorname{Lin} 17$ & 14.8 & 14.9 & 14.8 & 14.9 & 13.8 & 15.2 & 14.0 \\
\hline $\mathrm{T}$ & $L=-18$ & 15.1 & 15.2 & 15.2 & 15.2 & 13.5 & 14.2 & 14.0 \\
\hline $\begin{array}{l}I \\
\mathrm{C}\end{array}$ & $1-19$ & 15.3 & 15.3 & 15.4 & 15.3 & 14.8 & 15.2 & 16.9 \\
\hline$E$ & $L-21$ & 14.8 & 15.0 & 15.0 & 15.0 & 13.5 & 14.5 & 14.1 \\
\hline & $-4-23$ & 15.2 & 15.6 & 15.5 & 15.7 & 14.3 & 15.5 & 15.6 \\
\hline $\mathrm{P}$ & $I-25$ & 14.7 & 14.8 & 14.8 & 14.9 & $13 \cdot 3$ & 14.5 & 14.2 \\
\hline$I$ & $I=32$ & $11 \cdot 3$ & 10.2 & 10.0 & 9.8 & 10.7 & 11.2 & 11.5 \\
\hline 0 & $L-33$ & 13.9 & 14.0 & 14.0 & 14.0 & 12.4 & 13.1 & 12.8 \\
\hline $\mathbb{N}$ & $L=34$ & 13.6 & 13.5 & 13.5 & 13.5 & 13.8 & 15.0 & 15.2 \\
\hline$S$ & $I-35$ & $-\infty-\infty$ & $=-\infty$ & $-\infty$ & $-\infty-\infty-\infty$ & $-m-\infty$ & $-\infty-\infty$ & $-\infty-\infty$ \\
\hline & $I-36$ & $m-\infty$ & $m-\cdots$ & $-m-\infty$ & $\ldots-\infty$ & $-\cdots$ & $-m-$ & $\ldots$ \\
\hline & $\mathrm{L}-37$ & 15.1 & 15.2 & 15.2 & 15.2 & 12.4 & 14.2 & 13.8 \\
\hline & $L-30$ & 14.4 & 14.4 & 14.5 & 14.5 & 13.4 & $14 \cdot 3$ & $7.8^{*}$ \\
\hline & $L-39$ & 15.0 & 15.7 & 15.8 & 15.8 & 14.4 & 14.0 & 15.5 \\
\hline
\end{tabular}




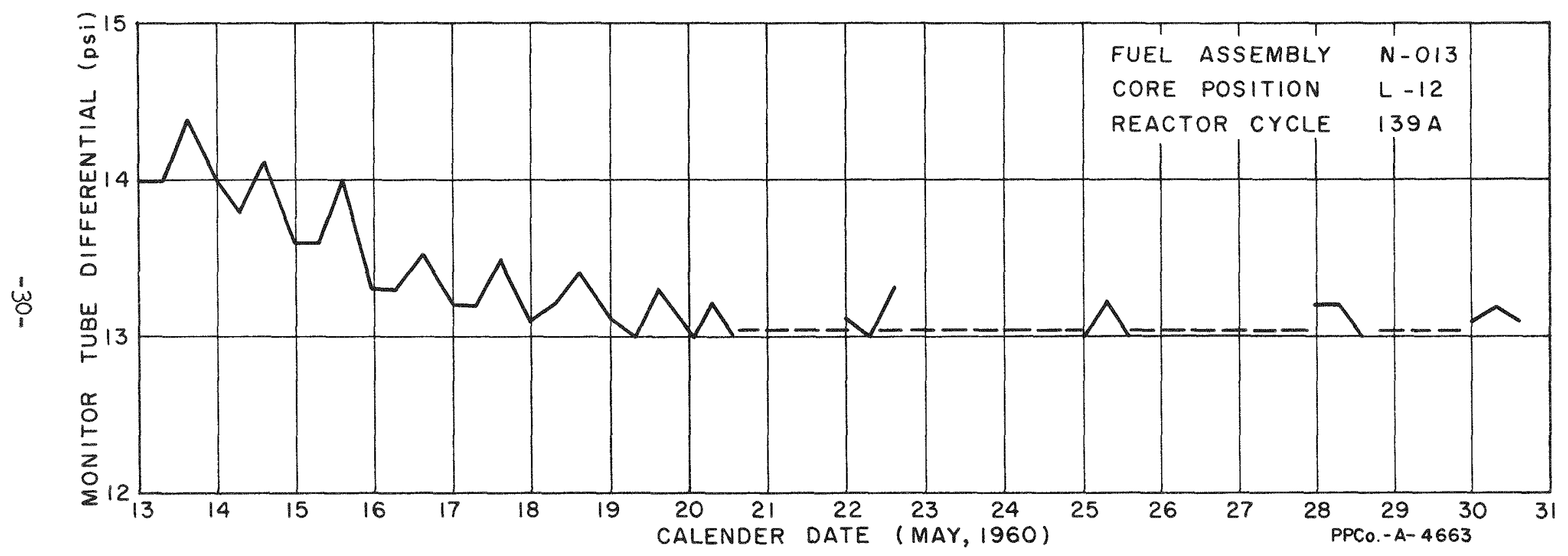

FIGURE 18 - Monitor Tube Data Indicating Fuel Assembly Failure 
Engineering and MTR Safeguard Comittee. The outcome of this review was four precautionary measures which were effected to insure safe reactor operation. The following is a summary of these measures:

(1) The fuel fabricator was informed of the situation and requested to take the necessary action to overcome the situation.

(2) At the end of each reactor cycle, the assemblies in the reactor were carefully inspected for additional failures. only those assemblies which had passed the inspection were recycled.

(3) The monitor tube data was more carefully observed during reactor operation. During reactor shutdown maintenance was performed on the monitor tubes to achieve proper monitor tube operation.

(4) All new assemblies were hydraulically tested prior to their initial reactor insertion.

b. Hydraulic Test Program

(I) General Progrem

Following the dimensional inspection of a new fuel assembly, it was hydraulically tested in the MTR-ETR hydraulic test facility. This facility permitted testing of one assembly in a geometric configuration which was a full scale mockup of a reactor core position. Each assembly was hydraulically tested to $140 \%$ of its nomal operating flow rate of $650 \mathrm{gpm}$.

The $140 \%$ test, which was utilized during ETR fuel assembly testing and development, effectively doubled the various pressure differentials acting on the various fuel assembly components. In addition, a statistical analysis was performed on the failure distribution of the $N$ series assemblies which were tested. Based on this analysis, an assembly which had passed a $135 \%$ flow test had a probability of failure in the reactor of 0.000 . 


\section{(2) Failure Examination}

To determine whether or not the 24 assembly failures

experienced during the hydraulic test program were attributable to incomplete brazing, 18 assemblies were sectioned as was $\mathbb{N}-122$. In each of the sectioned assemblies incomplete brazing was found. An example of the incomplete brazing is presented in Figures 19 and 20. These are photographs of one section of assembly $\mathbb{N}-146$. In Figure 19 the partially fused brazing wires and the lack of braze material in the joints can be noted. In Figure 20 four fuel plate sections which were completely devoid of any braze bonding have been displaced. It can be noted that this segment contained braze wires in various degree of fusion from complete lack of fusion to complete fusion.

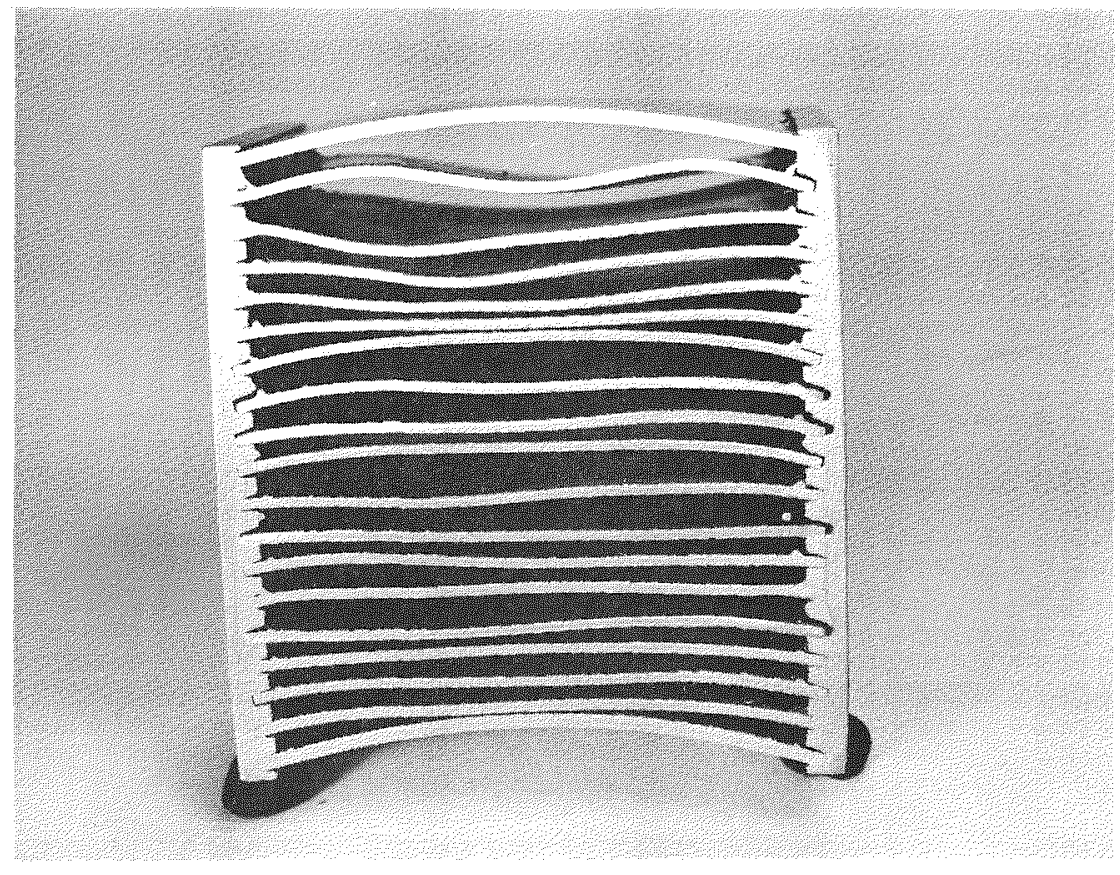

FICURE 19 - Segment of Failed. Assemb1y N-146 


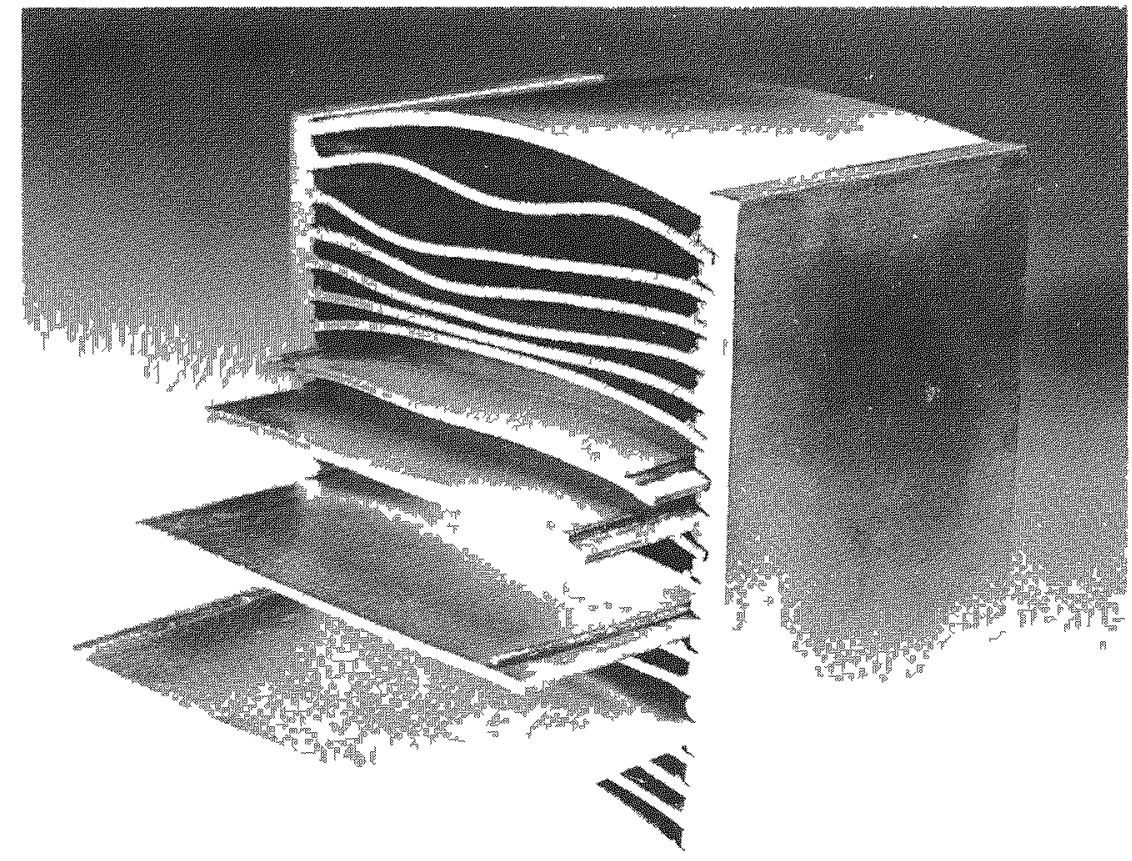

FICURE 20 - Unbrazed Plates Displaced From Tailed Segment

It was obvious from the failure examination that incomplete brazing was the cause of the assembly failures during the test program. These results, together with the results of the $N-122$ Inspection conclusively showed that the fabrication process was not in control.

\section{Long-Term Solution}

The most attractive long-term solution appeared to be the use of mechanically-assembled rathex than braze-assembled fuel assemblies. The mechanical assembly technique replaced the brazed fuel plate - side plate jolnt with a mechancal joint. This joint can be formed by a variety of methods with pinning and swaging being the two general categories of techniques. The two most significant advantages of the mechanical assembly technique are: (1) The fuel plates in the 
final assembly can be given some degree of hardening resulting in higher strength fuel plates. The brazing process anneals the plates thus reducing the strength of the plates. Reactor operation undoubtediy anneals the mechanically-assembled plates to some degree. There has been no indication, however, of complete annealing of the plates. Dead soft fuel plates in a mechanica.ly-assembled unit normally collapse during out-ofpile hydraulic testing whereas there have been neither out-of-pile nor in-pile deformation of hardened plates in mechanically-assembled MTR fuel assembiles. (2) By its very nature, the mechanical method permits closer surveillance of the fuel plate - side plate joint during its formation process. This in turn permits the fabricator to carry out quality control inspection to a greater degree than is possible while fabricating brazed assembizes.

The fuel fabricator who was under contract for the $N$ series assemblies rebrazed many of the assemblies which had been fabricated. The remainder of the assemblies called for by the contract were fabricated using the pinning technique of mechanical assembly.

The subsequent fuel fabrication contract was awarded to a new contractor who used the roll-swage technique of mechanical assembly. The following section presents the events which transpired under the subsequent contract.

In adition to the fuel assembly modifications, a number of steps were undertaken to place the monitor tube system in the best possible operating condition. This entailed the cleaning of plugged monitor tube pressure impulse lines, the installation of more reliable aifferential pressure cells, calibration of the monitor tubes, etc. 


\section{1961 Rol1-Swaged Assemblies}

1. First Failure

\section{a. Discovery of Failure}

Following the normal procedure for a change in fuel fabricator, the first twenty-five roll-swaged fuel assemblies from the new fabricator wexe hydraulically tested to $140 \%$ of the normal fllow rate. These tests were conducted in the MTR-ETR Hydraulic Test Facility and were 100\% successful. One out of every ten subsequent assemblies was also hydraulically tested prior to their reactor insertion. These tests were in addition to the external dimensional inspection performed on each assembly.

Approximately 60 roll-swaged assemblies were inserted in the reactor during a six month period prior to any indication of assembly failure. Each assembly normally experienced three reactor cycles. On November 27, 1961, following the termination of a reactor cycle, assembly J-6I was discharged from the reactor to the canal for shipment to the Chemical Processing Plant. While J-61 was being handled it was noted that its north side plate was bowed outward with a visible gap between a lower portion of the fuel plates and the side plate. Canal inspection of the fuel plates prior to removal of the end boxes showed no deformation of the fuel plates. Figure 2l is a photograph of the assembly as it was upon being discharged from the reactor. Minor distortions appear due to thermal gradients in the canal water resulting from fission product decay heat.

Upon cutting of the lower end box from the assembly, the north side plate further separated from the fuel plate bunde and the 


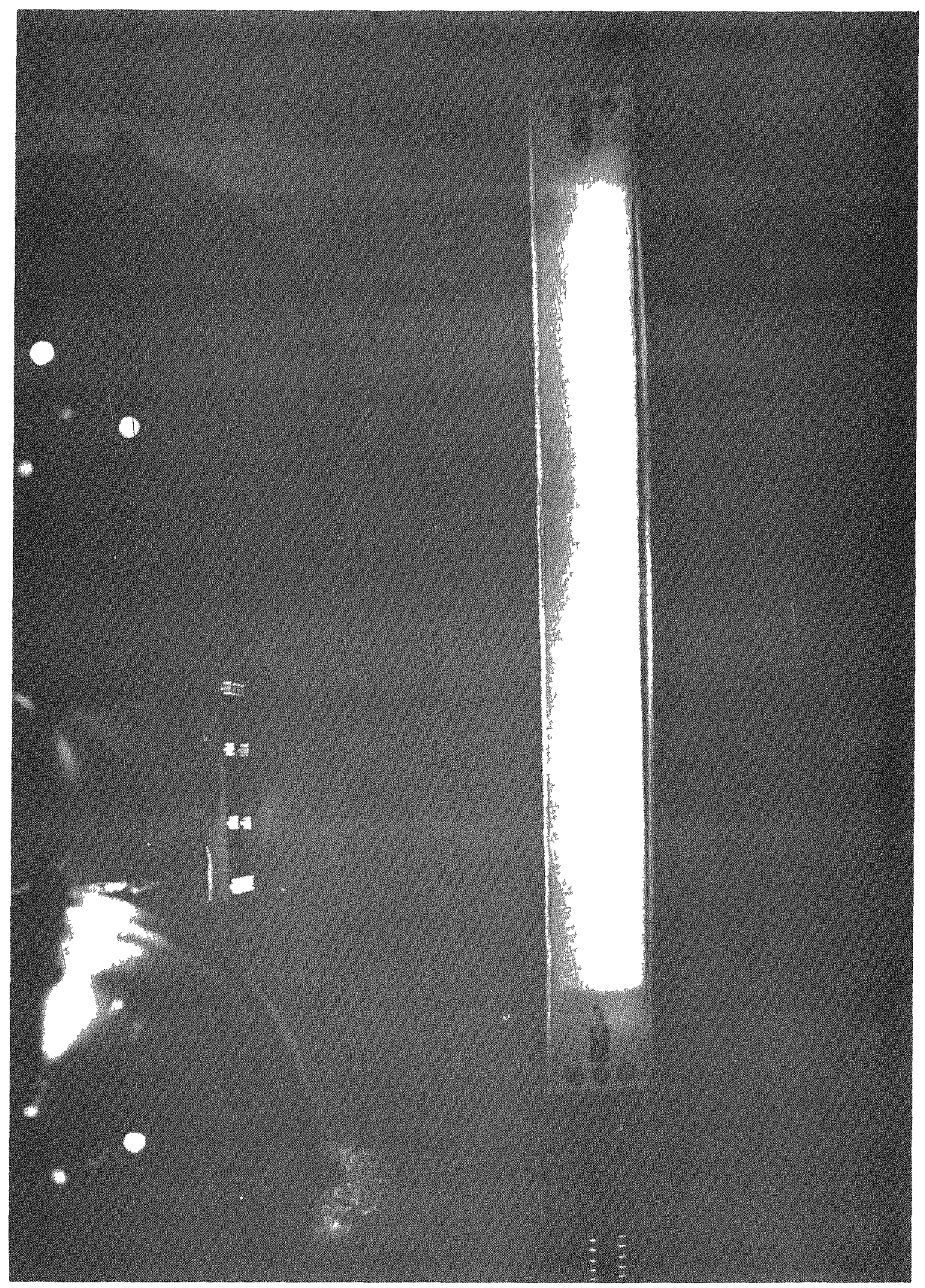

FICURA 21 - Assembly J-61 With Bowed side Plate 
south side plate began to come loose from the fuel plate bundle. Upon cutting of the upper end box from the assembly, the north side plate was completely free from the fuel plate bundle with the exception of being attached to the upper end of one outside fuel plate. When the north side plate was removed from the plate bunde, the outside fuel plate remained attached to it pulling free from the south side plate as well as the combs. Normally following the removal of the end boxes, the fuel plate side plate bundle is a firm, integral unit. Figure 22 is a photograph of the fuel plate bundle after the removal of the end boxes and the north side plate. This photograph was taken through the canal periscope.

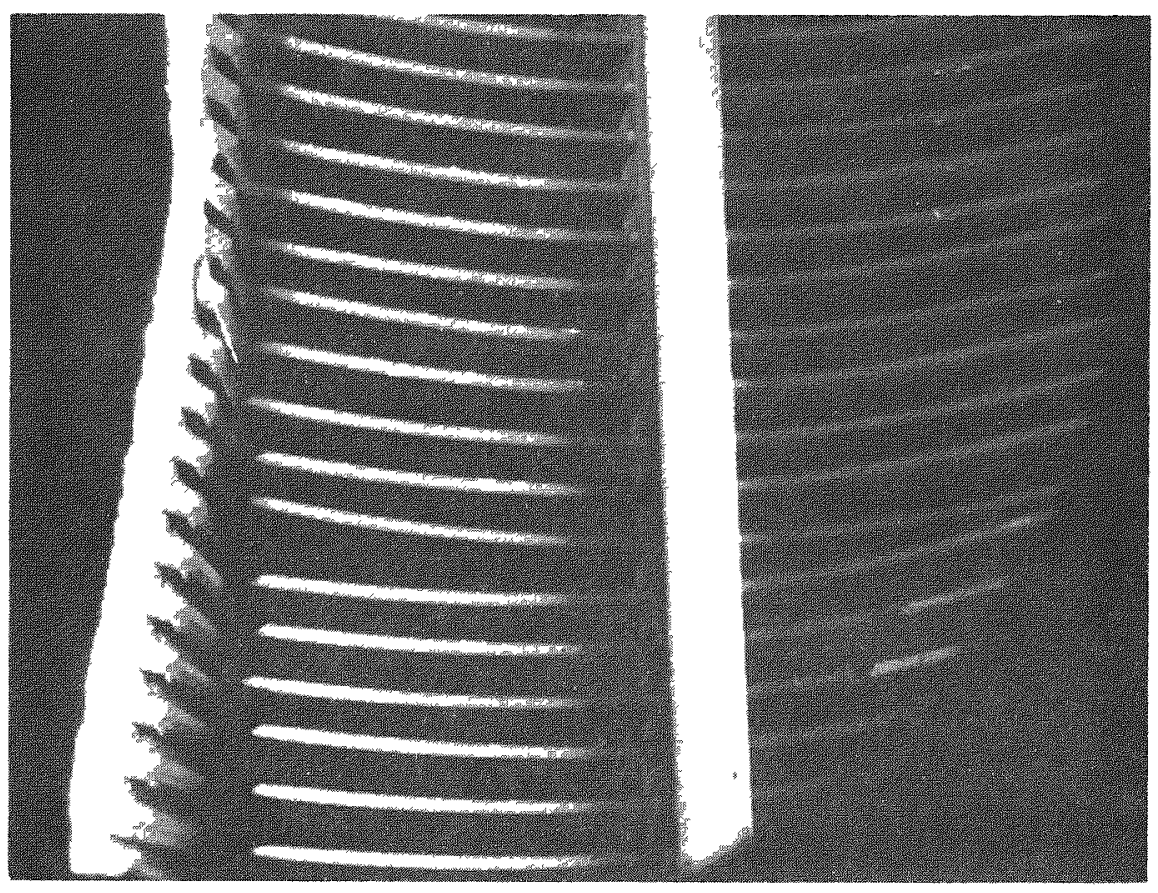

FIGURE 22 - J-61 With North Side Plate Removed 


\section{b. Cause of Failure}

The apparent cause of the feilure was improper swaging of the side plates onto the fuel plates. Figure 23 presents examples of improper swaging together with a properly swaged joint. To determine whether this failure was an isolated occurrence or the fabricator"s swaging process was out of control, a hydraulic test program which is discussed later, was initiated.

Improper die positioning results in either a thin web of side plate or a shallow web of side plate being swaged against the fuel plate. Improper centering of the fuel plate between the side plates prior to swaging again results in a shallow web of side plate being swaged against one edge of the fuel plate. Any of the above improper swaging conditions results in the fuel plates being weakly held by the side plate.

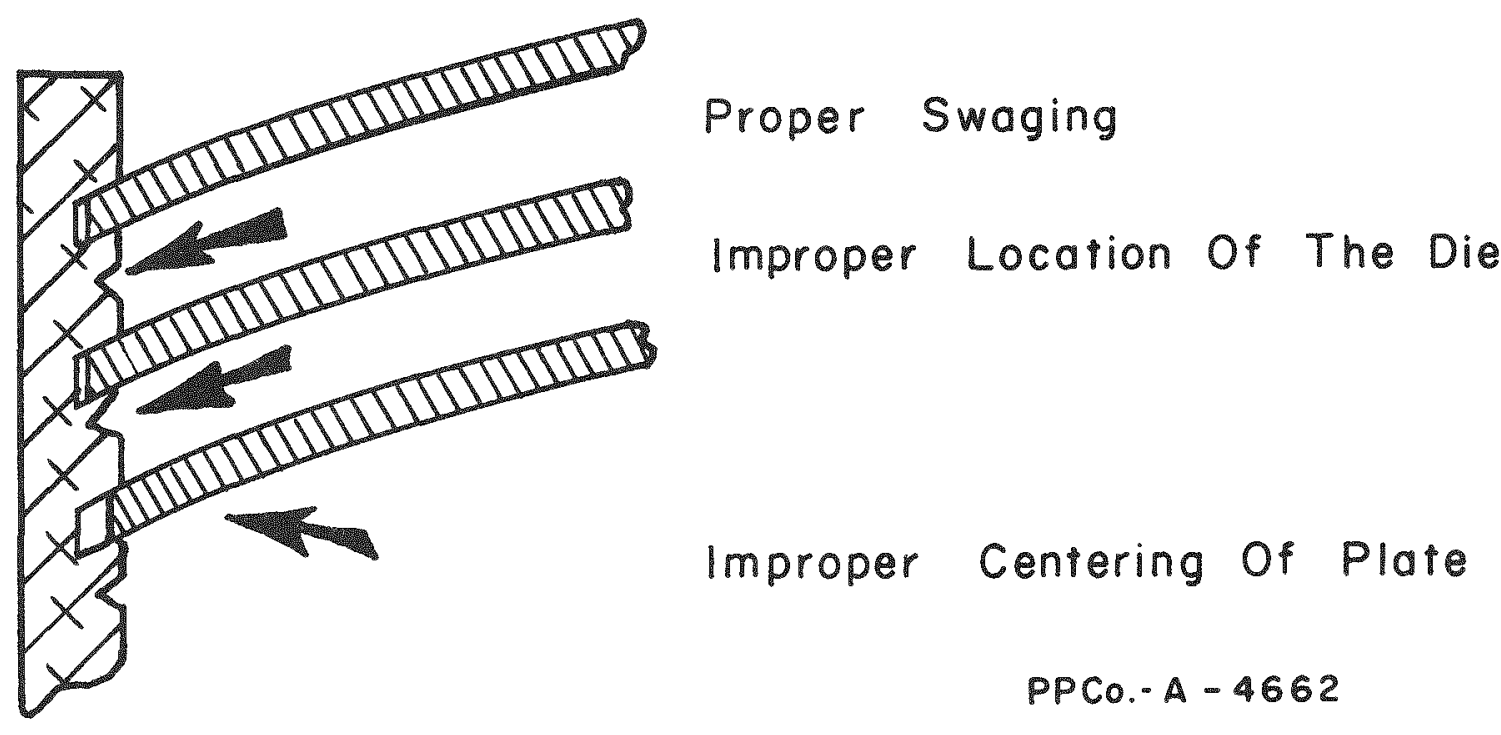

FIGURE 23 - Proper and Improper Swaging 


\section{c. Time of Failure}

Assembly $\mathrm{J}-61$ had operated in the reactor for three cycles, being in a different core position each cycle. During its third cycle the north side plate of $J-6 I$ was located adjacent to a control rod. Examination of the south side of this control rod revealed mub maxks on Its lower section. Normally there is an 0.068 in. clearance between a fuel assembly side plate and an adjacent control rod. These rub marks indicate that elther the failure or a gross change in the degree of failure occurred late in the third cycle.

A second set of evidence which indicated the time of failure was the abnormal behavior of certain reactor control instrumentation near the end of the third operating cycle of $\mathrm{J}-61$.

\section{d. Reactor Instrumentation Abnormal Behavior}

Approximately 48 hours prior to the end of the cycle under consideration, position $\mathrm{I}-34$ monitor tube pressure differential gage, the reactor period recorders and the three safety level recorders exhibited abnormal behavior. The monitor tube reading dropped approximately 2 psi resulting in an annunciator alarm. The period and level recorders began oscillating with an unusually large amplitude.

The output of the standby regulating-rod servomechanism preamplifier was monitored and recorded on a Brush recorder. This signal originated in an ion chamber. The amplitude of the full power signals was approximately double the normal full power signal amplitude. Past experience has indicated this type of instrument behavior to be indicative of boiling, presumably nucleate boiling, in the reactor core. Figure 24 presents a normal Brush recording together with the abnormal recording obtained at servo-system preamplifier output. 
NORMAL

OUTPUT

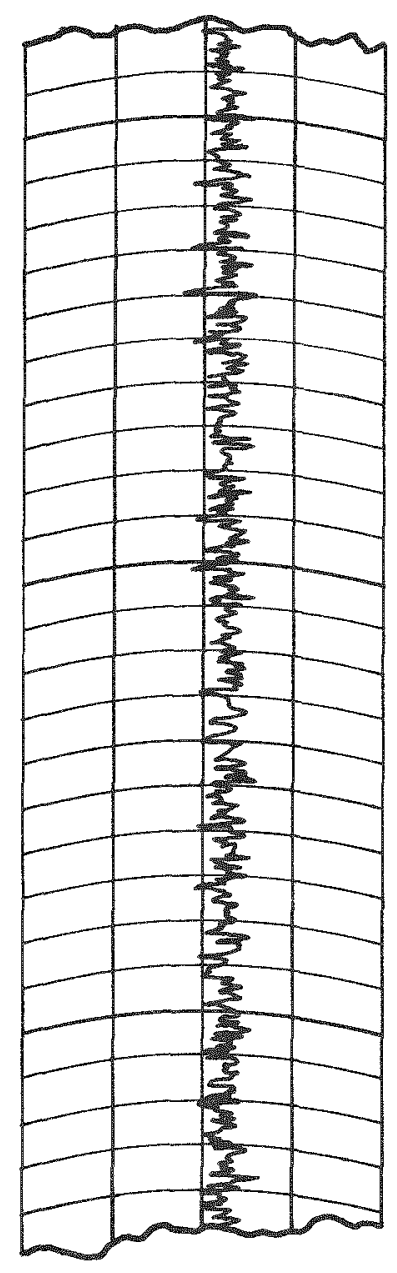

ABNORMAL OUTPUT

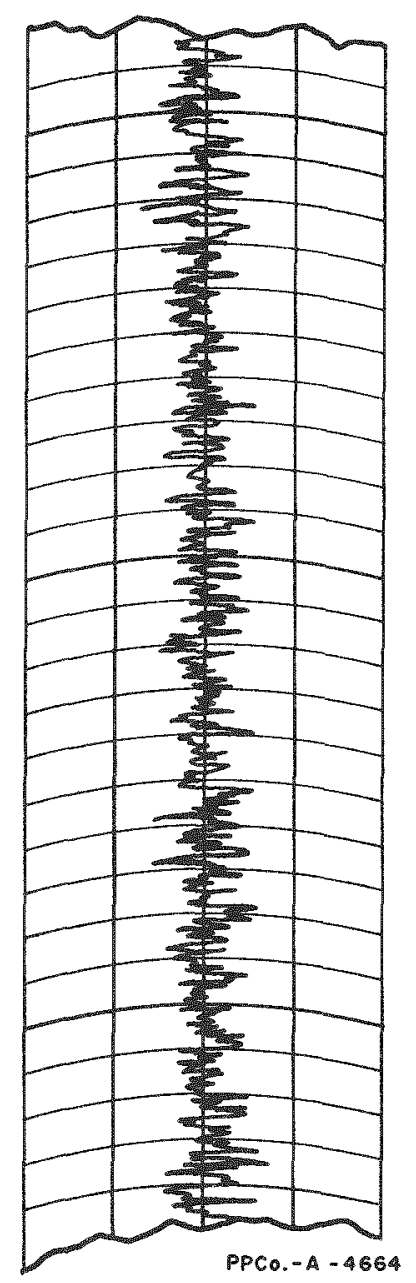

FICURE 24. - Servo Preamplifier output

At this point the reactor power was lowered from $40 \mathrm{MW}$ to $0.4 \mathrm{MW}$, to facilitate instrument checkout. The monitor tube impulse lines were purged and the electronic instruments were inspected with no malfunctions detected. The reactor power was then raised back to $40 \mathrm{MW}$ with all of the instruments again behaving normally. 
2. Second Filiure

a. Discovery of Failure

Bleven days after the failure of $J-61$ was discovered

the reactor instrumentation again exhibited abnormal behavior similar to the previous incident. In this case, however, the amplitude of standby servo system oscillations was somewhat less. Also, the monitor tube readings had decreased sifigtly over a period of several days immediately prior to the abnormal instrument behavior for position L-25. The reactor was immediately shut down and the fuel assembly in position L-25, assembIy J-53, was inspected along with the rest of the fuel assemblies in the core.

The north side of J-53 was bowed outward but to a Iesser degree than the bowed side plate of J-61. Assembly J-6́o, which was in position L-I5, appeared to have a very slight bow in one side plate but it was so slight that it was impossible to definitely say that it was bowed.

As in the case of $J-61$, the fuel plates themselves were not deformed in any of the assemblies.

\section{b. Cause of Faliture}

Upon removal of the end boxes from J-53, inspection again revealed the side plates to be improperly swaged onto the fuel plates. This again resulted in a weak assembly which was deformed by the pressure differential forces acting on the assembly.

It is of interest to note that assembly $J-53$ was in Its third cycle of operation at the apparent time of its failure; J-6I was in its third cycle of operation at the apparent time of its faliure. 
Assembly J-53 had been inspected prior to its third cycle insertion with no abnormalitied noted. This assembly was not subjected to a hydraulic test prior to its initial insertion.

The flow monitor tube for J-53 indicated a very gradual decrease in flow through the assembly during its third cycle. The total decrease amounted to approximately 0.75 psi. This occurrence could be interpreted as a creep type fallure of the assembly similar to the failure of a number of the brazed assembly failures in 1960.

\section{Operational Precautions}

a. Reactor Instrumentation Surveillance

Immediately following the J-6I failure, increased reactor instrumentation surveillance was re-established. Particular attention was given to the monitor tubes as was done in the case of the 1960 fallures. Oscillation of the reactor control instrumentation appeared to be an indication of side plate bowing thus particular attention was also given to this area. The oscillation of this instrumentation was the main indication of the J-53 failure.

\section{b. Hydraulic Test Program}

The roll-swaged fuel assembly hydraulic test program was designed to determine the integrity of the fuel plate - side plate bond. The following is the test procedure which was applied to each of the roll-swaged tuel assemblies on hand:

(1) The distance between the outside of the side plates was measured at 16 positions. This distance is nominally 3.996 in.

(2) The fuel assembly was subjected to $140 \%$ of its normal flow rate for 15 minutes. 
(3) The distance between the outside of the side plate was again measured at the same 16 positions.

(4) If none of the distances increased by more than $0.003 \mathrm{in.}$, the assembly was accepted for reactor operation. If any of the distances increased by more than $0.005 \mathrm{in.}$, the assembly was rejected for reactor operation. If any of the distances increased by 0.004 or 0.005 in., the assembly was retested.

(5) Following a 15 minute test at $140 \%$ of normal How, the 16 distances were again measured.

(6) If none of the distances increased, the assembly was accepted for reactor insertion. If any of the distances increased, the assembly was retested for an additional 30 minutes.

(7) If none of the distances increased during the 30 minute test, the assembly was accepted for reactor insertion providing that none of the distances increased more than $0.005 \mathrm{in}$. If any of the distances increased, the assembly was rejected for reactor insertion.

A total of 209 assemblies was tested. Of this total, 121 were accepted after their first test, 24 were accepted after retesting and 64 were rejected. Figure 25 is a photograph of one segnent of an assembly which failed during its hydraulic test. The faces of this segment were coated with a plastic matexial to prevent the spread of uranium contamination.

One hundred per cent testing continued until it was apparent from the test results that the fabricator had re-established adequate quality control. 


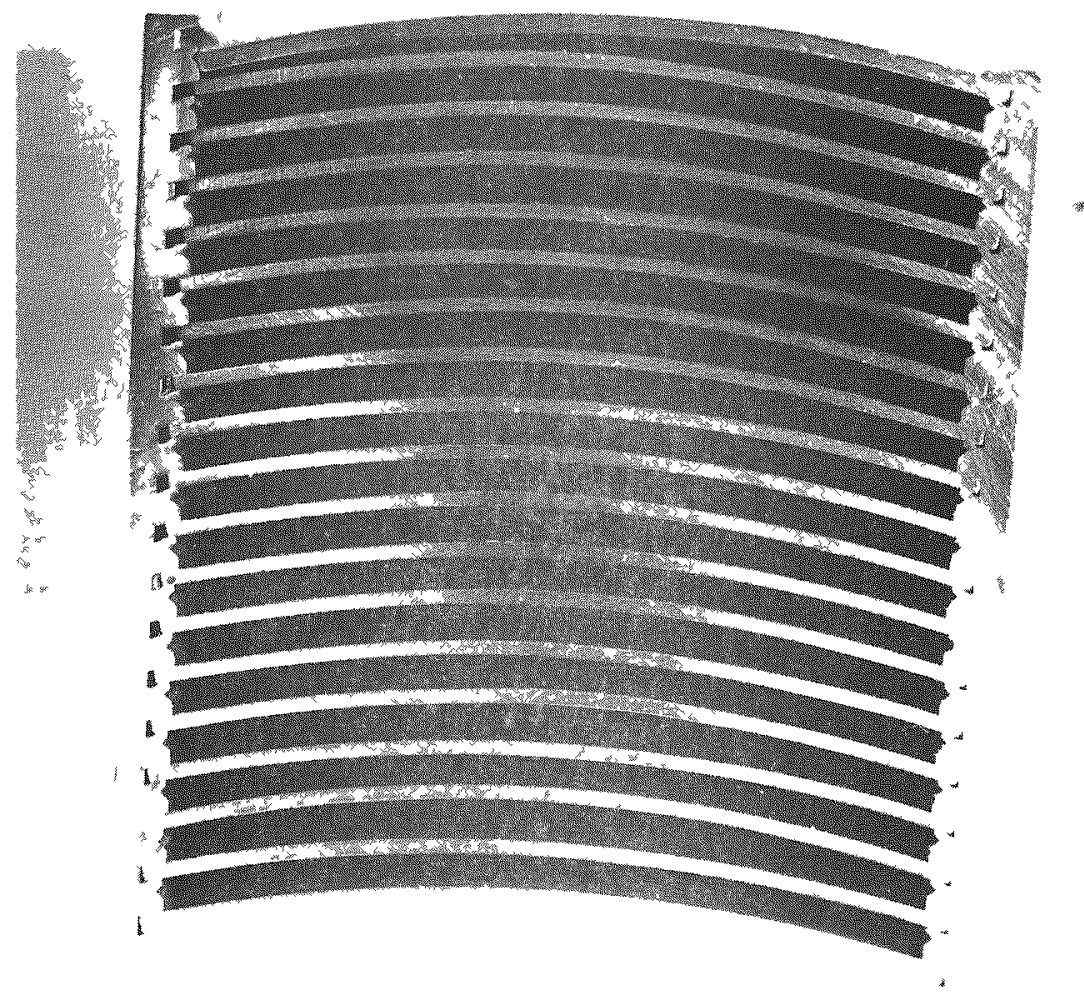

FIGURE 25 - Roll-Swabed AssembIy - Hydraulic Test Failure

c. Cycled Muel Inspecuion

During the entire period that fuel assemblies of

questionable mechanical integrity were being operated, each fuel assembly was inspected at the complotion of $\mathrm{cach}$ cycle. The inspection technique has been presented in section IV. 3. \%. a.

\section{Long Texm Solution}

The fabricator was nut ted of the in-pile failure and the apparent cause of the fail $\mathrm{k}$. 'Mllowing a hydraulic test failure of an asscmbly, its sectioning and olose examination, it was possible to further substantiate the postulated case of failure. The fabricator then took the necessary steps th rc-fstavlish adequate quality control over the fabrication process. 
The reactor has been operating for over one year with roll - swaged assemblies from the same fabricator with no adaitional failures encountered. Only the normal acceptance tests are being performed. These are presented in the following section. 
$+1$

de
d

$-46$

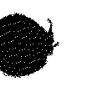

$$
6
$$

$$
6
$$




\section{Conclusions}

From the events related in this report, two primary lessons can be drawn. First, all design changes, no matter how small, must be fully evaluated prior to acceptance for reactor operation. Normally at MIR a prototype is fabricated, tested thoroughly prior to reactor insertion, carefully observed during reactor operation and thoroughly examined following discharge from the reactor. The particular example cited herein occurred early in the operating history of MTR and, hopefully, operating experience now permits more reliable appraisal of design modifications.

Second, a high degree of quality control should be exercised at each step of the fabrication process. This operation logically falls to the fuel fabricator since he should be able to rapialy detect and correct any phase that might go out of control. Proper quality control could have detected both of the deficiencies cited herein.

Nevertheless, it behooves the fuel purchaser to design and carry out test procedures to assure safe reactor operation. The acceptance tests performed on MIR fuel assenblies are summarized below:

1. Wach assembly is given an extemal dimensional inspection to assure proper fit in the core.

2. Each assembly is given a nucleonic assay scan (5) to determine its uranium content.

3. A hydraulic test is performed. Whenever the particular assemblies under consideration are the first units from a new fabricator, the first units from a new fabrication technique or the first units of a modified design, 25 assemblies are hydraulicaliy tested to $140 \%$ of their operating flow rate. For all other units, one out of each ten assemblies is randomly selected for hydraulic testing to the $140 \%$ Slow rate. 
Upon successfully completing these four tests, the assemblies are scheduled for reactor insertion.

Two aditional acceptance tests are currently being designed and will become operational soon. This first test entails measuring the thickness of some of the coolant channels. The second test entails determination of fuel homogeniety from radiographs of the fuel plates.

$\underline{A} \underline{C} \underline{\mathbb{N}} \underline{O} \underline{\mathrm{W}} \underline{\underline{E}} \underline{\mathrm{D}} \underline{\mathrm{G}} \underline{\mathrm{M}} \underline{\underline{E}} \underline{\mathbb{N}} \underline{\mathrm{T}}$

The author wishes to acknowledge the valuable assistance of

W. M. Hawkins, J. D. Ford, E. S. Brown and W. S. Little in the preparation of this report. 


\section{$\underline{R} \underline{E} \underline{E} \underline{E} \underline{E} \underline{N} \underline{E} \underline{S}$}

(1) T. R. Wilson and O.J. Elgert, "Hydraulic Tests in the MTR Lattice", IDO-16308 (November 15, 1954).

(2) J. R. Huffman, "MIR Technical Branch QuarterIy Report [for] Third Quarter, 1954", IDO-10209) (December 21, 1954).

(3) J. R. Huffman, "MIR TechnicaI Branch QuartexIy Report [for] Fourth Quarter, 1954", IDO-16219 (March 31, 1955).

(4) "Fuel Elements Conference Held at Gatlinburg, Tennessee, May 14-16, 1950", TID 7559 (Part 1) (Paper 3).

(5) F. H. Tingey, "Nondestructive Fuel Assay at NRTS", Nucleonics 7, $76-01$ (1962). 